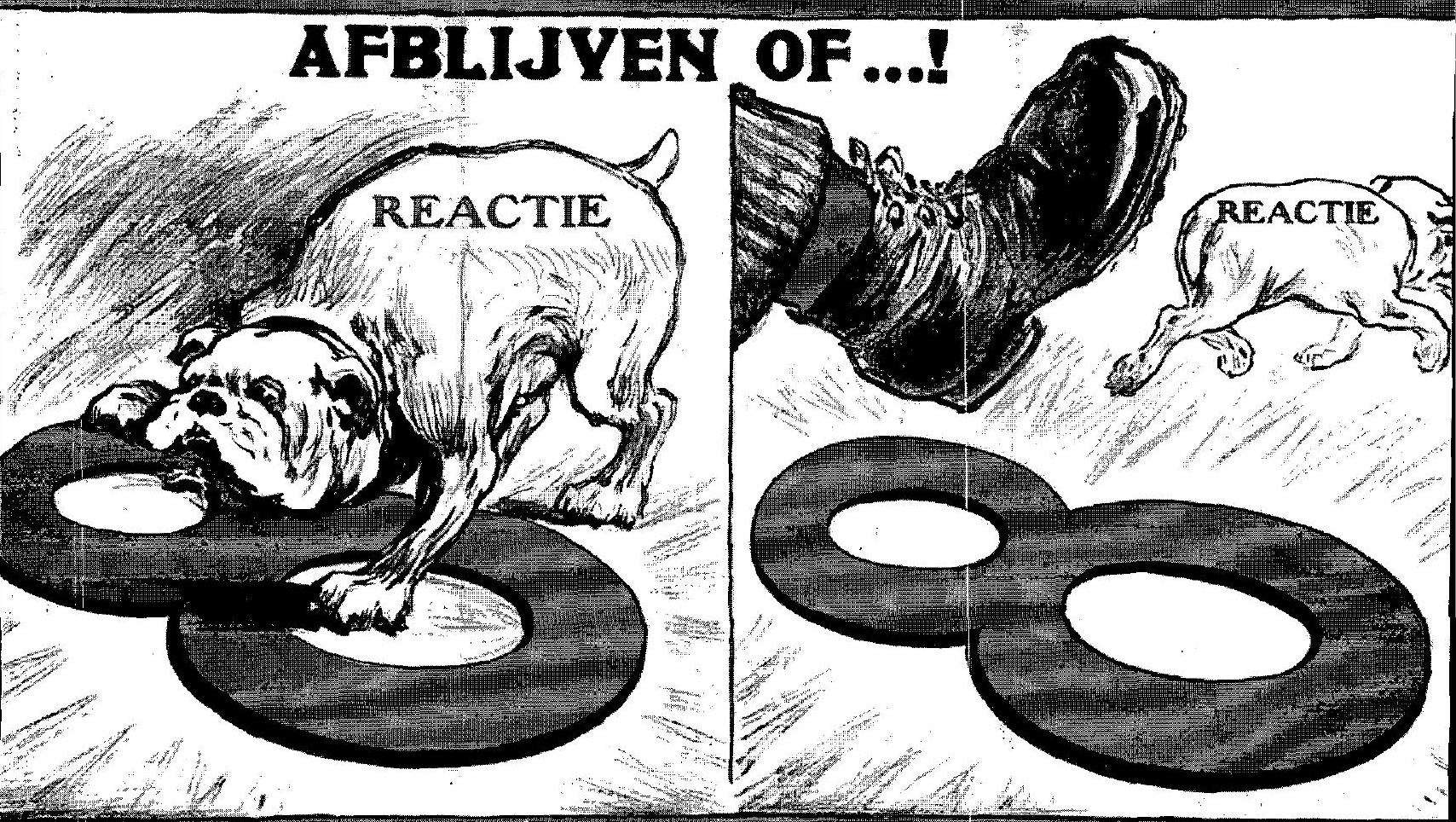




\section{Begeesterd door de telduivel.}

\section{De ledencijfers van de socialistische}

$\rightarrow$ vakbeweging in het interbellum opnieuw bekeken

Kurt Vandaele, aspirant FWO-Vlaanderen, Universiteit Gent

Vakbonden zijn ledenorganisaties. Zowel vroeger als nu vormen de leden de meest in het oog springende bron van vakbondsmacht. Uiteraard impliceert het begrip vakbondsmacht veel meer, maar een studie van de vakbondsfuncties start het best bij de ledenaantallen. Een excursie in de bestaande publicaties omtrent de ledencijfers van de Syndikale Kommissie (SK) en het latere Belgische Vakverbond (BVV) leert dat er tot op heden enige verwarring bestaat over deze cijfers. Na enkele methodologische beschouwingen, willen we door middel van een kritisch bronnenonderzoek deze onduidelijkheid wegnemen. Gekoppeld aan een verkennend onderzoek naar de structurele evolutie van de socialistische vakbeweging, reconstrueren we de ledenciffers van de SK en het BVV opnieuw voor het tussenoorlogse tijdvak (1919-1939).

\section{Inleiding}

De Leuvense politicoloog Wilfried Dewachter klaagde recentelijk dat “(...) de officiële politieke statistiek in België (...) is verschrompeld tot (...) een eerder onbeholpen corpus"(1). Geen beter voorbeeld om Dewachters vaststelling te illustreren, dan te verwijzen naar het ontbreken van enig 'officieel' statistisch basismateriaal, in casu de ledencijfers van de Belgische vakbeweging: "There is no official coverage of union membership statistics in Belgium, neither by the Statistical Bureau, nor by the Labour Ministry"(2). De Amsterdamse arbeidssocioloog Jelle Visser vult bovendien aan dat "(...) in the field of interest organizations we are in a less 
privileged position than in electoral research where students can draw on rich databases of official electoral statistics, surveys and documents. Interest representation via trade unions (...) are less and by all means less uniformly institutionalised"(3). Geen wonder dat de Belgische vakbonden een weinig gegeerd onderwerp zijn in internationaal (vergelijkend) onderzoek. In eigen land beperkt het onderzoek naar de Belgische vakbeweging zich tot een eerder descriptiefkwalitatieve benadering en dat terwijl "over the past four decades quantitative research has extended into all branches of history"(4).

Het verschijnen van het datahandboek, Trade Unions in Western Europe since 1945, kan in deze 'statistische' impasse verandering brengen. Zoals de titel al aangeeft, blijft het echter koffiedik kijken voor wat de periode vóór 1945 betreft. Zodoende blijft er (minstens) één 'statistisch' obstakel voor wie, bijvoorbeeld, een longitudinale studie van de Belgische syndicalisatiegraad - de ratio die het aantal vakbondsleden op het potentiële aantal leden meet - wil aanvatten.

Een belangrijke aanzet tot het berekenen van de Belgische syndicalisatiegraad in het interbellum is evenwel de studie van Patrick Pasture en Jozef Mampuys, In de ban van het getal. In deze publicatie gaan de auteurs op een minutieuze wijze de ledencijfers van het Algemeen Christelijk Vakverbond (ACV) voor de periode 1900-1990 na. Vooralsnog blijft een dergelijke kritische analyse voor de ledencijfers van de socialistische vakbeweging uit. Nochtans is er de uitnodiging uit 1959 van Hubert Dewez, pseudoniem van Jean Neuville, "Là où nous n'avons pu découvrir les chiffres, nous avons laisséle blanc nécessaire qui permettra au lecteur, si la chance le favorise, de compléter les tableau $x^{\prime \prime(5)}$.

\section{Een poging tot reconstructie en aanvulling}

$\mathrm{Na}$ eerst de gangbare cijferreeksen kritisch te hebben overzien, stellen we onze methodologie op. We beoordelen daarbij het bronnenmateriaal in termen van betrouwen beschikbaarheid. Belangrijk om weten is hoe de socialistische vakbonden zelf hun ledenaantal bepalen. Bestaan er verschillen tussen de verschillende vakbonden? Houden de vakbonden bijvoorbeeld rekening met gepensioneerde of zieke leden bij het berekenen van het ledencijfer? Worden werkloze leden meegerekend? Eenmaal hier duidelijkheid over is, kunnen we onze ledenreeks voor het interbellum samenstellen. Voor we daartoe overgaan, schetsen we eerst nog even de structurele evolutie van de socialistische vakbeweging en maken we een zijsprongetje door summier de propagandavoering en ledenwerving te beschrijven. Eenmaal we ten slotte een nieuwe cijferreeks bekomen hebben, toetsen we deze op haar geldigheid. Na de voornaamste ledenontwikkelingen te hebben geduid, volgen onze conclusies. 


\section{Cijferchaos}

Als we even in de bestaande publicaties over de ledenaantallen van de socialistische vakbonden in het interbellum grasduinen, komen we tot de conclusie dat er merkbare verschillen zijn (bijlage 1, p. 28). In zijn Une génération syndicale baseert Neuville zich op Jean Bondas' Een halve eetw syndicale actie, 1898-1948 (kolom 6). Evenwel rapporteert Neuville ook de ledencijfers die Emile Vandervelde publiceerde in Lecinquantenaire du P.O.B. (kolom 5). Het is zo klaar als een klontje dat Vandervelde uitging van de cijfers die de SK meedeelde in haar zedelijke en geldelijke verslagen (kolom 2). Op haar beurt baseerde de SK zich op de 'mededelingen' van de diverse centrales. Het verschil tussen de cijferreeksen van Vandervelde en Bondas verklaart Neuville door "une différence de comptabilisation". Ten slotte publiceerde Neuville ook de ledencijfers per aangesloten centrale, maar telde ze niet op. Wij maken deze oefening wel (kolom 7): alleen voor de jaren 1919, 1929 en 1936 verschillen deze cijfers van deze van de SK (kolom 2). Verwarring troef dus: in Une génération syndicale vinden we in feite drie cijferreeksen terug( ${ }^{(6)}$. De verslagen van de SK bieden een verklaring.

De SK publiceerde immers niet alleen de ledencijfers gebaseerd op de mededelingen van de verschillende centrales over de zogenaamde 'ingeschreven leden', maar ook op de ontvangen of betaalde bijdragen van de diverse centrales (aan de SK) (kolom 3). Voor de periode 1919-1937 liggen de ledencijfers gebaseerd op deze mededelingen gemiddeld 27.763 eenheden hoger dan deze gebaseerd op de betaalde bijdragen (kolom 4). Zo merkwaardig is deze discrepantie nu ook weer niet. De ledencijfers opgegeven door de centrales werden geregistreerd op 31 december, terwijl de andere ledenaantallen betrekking hebben op het gemiddelde van de ontvangen bijdragen van het laatste kwartaal van elk jaar.

De cijfers gebaseerd op de betaalde bijdragen vertonen dan weer aardige overeenkomsten - zij het niet altijd - met de ledenaantallen die Bondas opgeeft. Bondas' cijferreeks vertoont aldus een arbitrair karakter: hij baseert zich grotendeels op de getallen op basis van de betaalde bijdragen, maar soms vormen de mededelingen door de centrales (1927, 1928, 1934, 1935 en 1936) de basis voor het ledenaantal. Enige vorm van argumentatie voor deze (willekeurige) benadering vinden we niet terug bij Bondas. De historicus Guy Vanthemsche signaleert dit cruciale gegeven eveneens: "Voor de ciifers na 1945 zegt Bondas (...) uitshitend leden volledig in orde met de bijdragen te hebben opgenomen. Hij baseerde zich dus niet op de ingekomen inschrijvingen. Het is echter niet expliciet duidelijk of hij dit ook toepaste op de cijfers vóór 1940, waarvoor hij dan op oorspronkelijk bronnenmateriaal zou steunen"(7). Het hoeft geen betoog dat het onderscheid tussen de ledencijfers gebaseerd op de mededelingen en deze gebaseerd op de bijdragen bij menig auteur of onderzoeker tot verwarring leidt.

Het gebrek aan homogene en betrouwbare ledencijfers voor de socialistische vakbeweging in het interbellum is nu duidelijk aangetoond. 


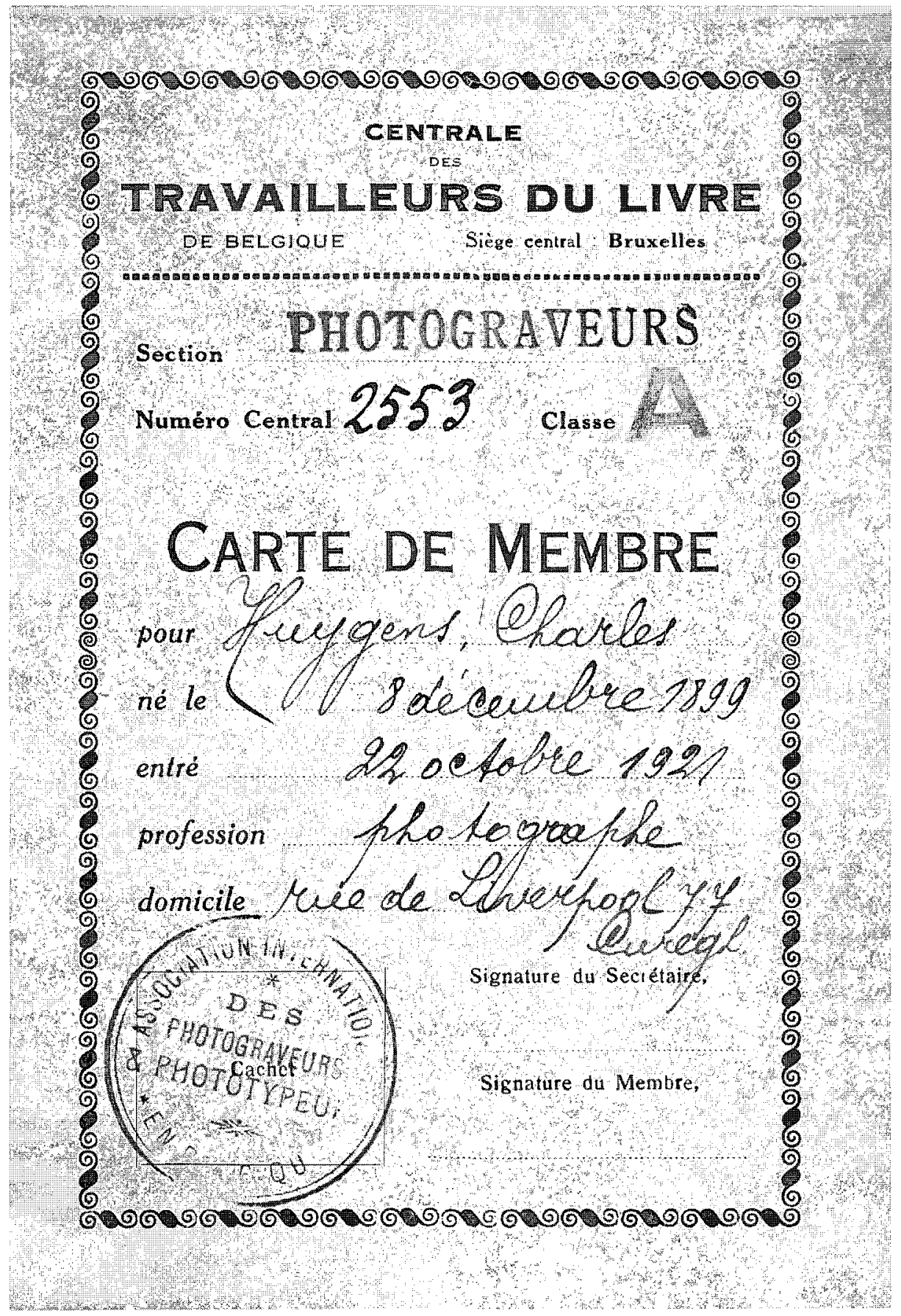




\section{Methodologie en bronnenkritiek}

\section{Nationale centrales of federaties}

Ons vertrekpunt voor analyse en observatie is, net zoals bij Bernhard Ebbinghaus en Jelle Visser, de nationale vakbondsorganisatie, namelijk de centrale of federatie als lid van de SK. De auteurs bestempelen de nationale vakbondsvereniging als de basiseenheid van de vakbondsorganisatie omdat zij zowel de 'logic of membership' als de 'logic of influence' bepaalt ${ }^{(8)}$. De nationale centrales zijn met andere woorden 'de pijlers van het socialistische syndicalisme': "Z $Z$ ij regelden de werking van de plaatselijke en de gewestelijke afdelingen, controleerden het syndicale reilen en zeilen en beheerden de fondsen die de stakings-, werkloosheids-, ziekte- en overlijdenskassen moesten spijzen"(9). Vanthemsche opperde al eerder deze werkwijze. Dat de nationale centrales of federaties hun machtspositie ten opzichte van de lokale vakbonden door de concentratie- en centralisatiebeweging in het interbellum (cf. infra) verstevigen, versterkt onze uitgangsstelling. Daarenboven erkent de SK vanaf 1907, de facto na 1919, nog louter nationale centrales of federaties. Tenslotte neemt de belangstelling voor de eigen organisatie in de socialistische beweging toe net voor de Eerste Wereldoorlog; daarom tolereert de SK niet langer de geflatteerde ledencijfers van de mijnwerkerscentrale in 1913. Het spreekt voor zich dat we door deze methode nieuwe cijferreeksen zullen bekomen.

\section{Passieve versus actieve vakbondsleden}

Wie beschouwen we nu als lid van deze nationale vakbondsorganisaties?

We bepalen het aantal vakbondsleden op basis van de betaalde bijdragen. De Algemene Centrale (AC) ${ }^{(10)}$ van de SK schrijft hierover zelf: "Wij hebben (...) gemeend het ciffer der afgerekende bijdragen als basis te moeten nemen, ondat dit ons de eenige zuivere en emstige berekening toeschijnt die de werkelijkheid het meest nabijkomt." Alras echter verlaat de AC dit valabele uitgangspunt, want: "In feite is evenvel het werkelijk getal leden beduidend hooger, omdat in elke afdeeling, hoe klein ze ook moge zijn, het materieel onmogelijk is van elk lid tot zijn laatste bijdrage te ontvangen, en dit om verschillende door onze afdeelingsbesturen genoeg gekende reden." De AC concludeert om "(...) aan deze getallen een zeker procent toe te voegen om het werkelijk getal leden zooveel mogelijk te benaderen. Wij nemen aan dat dit meerbedrag op 10 t.h. kan geschat worden." Soortgelijke ramingen om het "werkelijke' ledenaantal vast te stellen, vinden we terug bij de Centrale der Metaalbewerkers (CMB) (6 à 7\%), de Centrale der Spoorwegen, Post, Telegraaf, Telefoon, Marine en Luchtvaart (10\%) en het Nationaal Syndikaat van het Burgerpersoneel van Landsverdediging $(10 \%)$.

Wat evenwel niet betekent dat er sprake is van een structurele manipulatie van de ledencijfers, maar de stap naar een 'correctiecoëfficiënt' is niet zo groot meer. De vrij halfslachtige en dubieuze pogingen van deze centrales om het 'werkelijke' ledenaantal te bepalen, kaderen in een breder debat omtrent de zogenaamde passieve tegenover actieve vakbondsleden op de arbeidsmarkt. Vermits we ons op de effectief betaalde 
ledenbijdragen baseren, nemen we de passieve vakbondsleden, meestal gepensioneerde, maar evenzeer dienstplichtige of langdurig zieke leden, die allen doorgaans vrijgesteld werden van de vakbondsbijdrage, niet op. Ook de Centrale van Transportarbeiders (CTB) dacht er zo over: "Wij kunnen wel opgeven hoeveel leden er in de afdeelingen als zoodanig geboekt staan, doch dit aantal als het werkelijke ledental aanvaarden zou zelfbedrog zijn. We houden ons daarom aan den regel (...) om het totaal verkacht wekelijksche bijdragezegels als basis van het ledental te nemen"(11). Het formele bewijs van een betalend lid van de (socialistische) vakbeweging is met andere woorden een zegel op de lidkaart of in het lidboekje.

Het is allicht weinig verrassend dat er tussen de actieve en passieve vakbondsleden regelmatig verschillen in de congresrapporten en -verslagen van de SK optreden. De SK verklaart deze divergenties "(...) uit het feit dat vele organisaties van hunne uitgetrokken en gepensioeneerde leden geene bijdrage verlangen en dus voor hen aan de Syndikale Kommissie niet aanbetalen"(12). Enig opportunisme hierin is de SK niet vreemd. Deze verschillen zijn soms een handige manier om een daling van de ledencijfers te camoufleren. In het jaarverslag van de SK voor 1921 klinkt het bijvoorbeeld dat: "Alhoewel in het geheel een ledenverlies van 20,326 eenheden te boeken hebbend, we in feite onze posities versterkt hebben. Inderdaad, voor het laatste kwartaal 1920 hadden we 687,610 bijdragen ontvangen, en voor het vierde kwartaal 1921 was dit aantal tot 689,236 gestegen, aldus eene winst van 1,626 bijdragen boekend"(13). Ook het omgekeerde komt voor. Door gewiekst een verschillende vergelijkingsbasis te gebruiken, stelt de SK een grotere toename van het ledental voor dan in werkelijkheid. In 1919 vergelijkt de SK haar ledenaantal, gebaseerd op de meldingen van de nationale centrales met.de ledencijfers gebaseerd op de betaalde bijdragen uit 1914. We voegen er nog aan toè dat de socialistische vakbeweging klaarblijkelijk alleen in het interbellum het onderscheid makt tussen actieve en passieve vakbondsleden. Vóór 1914 en ná 1945 vinden we louter ledenaantallen terug op basis van de betalende leden. Op zich biedt deze vaststelling uiteraard niet meer garantie op betrouwbare ledencijfers dan de ledenreeksen uit het interbellum.

We maken geen onderscheid tussen de werkloze en werkende vakbondsleden. Alhoewel hier de schaarse data ons parten spelen, verantwoorden we deze optie vanuit meer fundamentele overwegingen. Een dergelijk onderscheid is vooral van belang voor de periode ná 1945. De literatuur met betrekking tot de naoorlogse syndicalisatiegraad maakt vaak een onderscheid tussen de netto en de bruto syndicalisatiegraad teneinde vergelijkingen tussen landen niet mank te laten lopen. Vooral landen waar het 'Gentse systeem '(14) of een afgeleide ervan (nog steeds) in voege is, vertonen de neiging tot een sterke divergentie ten opzichte van landen die dit systeem niet gebruiken. Vermits in het interbellum bijna het merendeel van de (westerse) landen voor het Gentse systeem opteerde, brengt dit, bij het berekenen van de Belgische syndicalisatiegraad, het vergelijken niet in het gedrang. Daarenboven is er bij het onderscheid tussen de netto en de bruto syndicalisatiegraad hoe dan ook enige nuance nodig omdat deze een opvallende grote samenhang vertonen. 
Ten slotte beperkt ons onderzoek zich tot het peilen naar het globale ledenaantal van de SK. We gaan niet in op de ledencijfers van de gewestelijke verbonden of de verschillen tussen bepaalde sociologische groepen (vrouwen, jongeren, 'vreemde' arbeidskrachten). Onder meer het gebrek aan continuiiteit van de data ligt aan de basis van deze beperking.

\section{Registratiebasis en -moment}

Onze basiseenheid van tijd is het kalenderjaar. In de literatuur gebeurt de registratie van het ledenaantal normaliter op 31 december en betreft het jaargemiddelden. We nemen deze methode over. Vanzelfsprekend zijn er andere mogelijkheden. De ledenaantallen die op de ingeschreven leden betrekking hebben, zijn om een aantal redenen geen geldig alternatief; ook de passieve leden maken deel uit van deze cijferreeks. Bovendien is niet alleen de registratiebasis betwistbaar, maar ook het registratiemoment. Het is immers twijfelachtig of dit moment, 31 december, voor iedere nationale vakbondsorganisatie hetzelfde is. Het registratiemoment in het vierde kwartaal van elk jaar, met andere woorden het ledengemiddelde van de laatste dertien weken - het aantal weken in een kwartaal - van het kalenderjaar bepalen is wel een alternatief. Toch is ook hier enige voorzichtigheid geboden. Specifieke wervingscampagnes, maar vooral het betalen van achterstallige bijdragen doen het ledental kunstmatig stijgen.

Welke methode, het jaargemiddelde of een momentopname zoals het vierde kwartaalcijfer, verdient de voorkeur? Pasture en Mampuys antwoorden dat: "In principe momentopnamen beter de potentiële 'reikwijdte' of 'invloedssfeer' aan [geven] van een organisatie. Gemiddelde ledenaantallen daarentegen geven juister aan wat de permanente (financielle) ledensterkte is. (...) Overigens zijn gemiddelden normaliter een stuk stabieler dan momentopnamen, die in de loop van een jaar sterk kunnen verschillen" (15). Voor wat de periode na 1945 betreft baseerden de auteurs zich dan ook op de gemiddelde ledencijfers. Vermits zij niet over de gemiddelde ACVledenaantallen beschikten, gebruikten ze uit praktische overwegingen ledencijfers als momentopnamen voor 1945.

In tegenstelling tot Pasture en Mampuys kunnen we voor ons onderzoek wel jaargemiddelden becijferen. Ons uitgangspunt is de nationale vakbondsorganisatie. Idealiter bekomen we het jaargemiddelde door het jaarlijks verkochte aantal zegels te delen door 52 (weken). Als we de hoeveelheid verkochte zegels niet kunnen achterhalen, zijn er - althans als deze betrekking hebben op de betalende leden - de week-, maandof kwartaalcijfers. Hebben we geen interne bronnen, rapporten en verslagen of andere secundaire bronnen over de nationale vakbondsorganisaties waaruit we direct of indirect het jaargemiddelde kunnen afleiden, dan beroepen we ons op de congresrapporten en -verslagen van de SK. Deze vermelden immers niet alleen de ledencijfers voor het vierde kwartaal, maar ook voor de vorige drie kwartalen. De vraag is: welke waarde kunnen we toekennen aan deze bronnen? 


\section{Betrouw- en beschikbaarheid}

Het is vrij plausibel te veronderstellen dat interne ledencijfers de geloofwaardigste bron vormen. Secundaire bronnen, zoals ledenstatistieken in congresrapporten en verslagen, zijn minder betrouwbaar. Zo zijn bijvoorbeeld de ledentabellen in het SKverslag voor 1919 onvolledig. Bovendien kunnen secundaire bronnen er allerlei redenen toe hebben de ledencijfers positief of negatief te manipuleren met als doel een vals beeld te geven van de 'ware' sterkte van de vakbondsorganisatie tegenover de publieke opinie, het patronaat, andere vakbonden of zelfs de eigen leden ${ }^{(16)}$. Deze opmerking mag echter niet tot verkeerde conclusies leiden: "Malgré tous les griefs que l'on peut adresser aux chiffres publiés par les syndicats, les interprétations que l'on peut en faire, ne sont, à notre avis, nullement erronées"(17). Ten slotte resten er de ledenaantallen gepubliceerd door derden. Deze beroepen zich in principe op de eerste twee bronnen, maar hebben het potentieel tot controle. De mate van betrouwbaarheid van een bron is één zaak, de beschikbaarheid ervan een andere.

Interne ledencijfers zijn uiterst moeilijk te achterhalen. Ook de congresrapporten en verslagen van de nationale centrales zijn niet altijd bewaard gebleven. Indien ze wel beschikbaar zijn, geven ze soms het ledenaantal helemaal niet of op een indirecte manier prijs. De toegankelijkheid vergroot echter wanneer we de congresrapporten en -verslagen van de confederatie, hier de SK, in beschouwing nemen, maar daarmee verlaten we evenwel ons uitgangspunt van analyse (cf. supra). Andere bronnen, die in principe de eerder geciteerde bronnen gebruiken, zijn het vakblad van de SK, De Belgische Vakbeweging, de respectievelijke ledenbladen van verschillende nationale centrales en het Arbeidsblad van het ministerie van Arbeid. Als we nu de evolutie van de ledencijfers in kaart willen brengen, moeten we eerst het verband met de structurele ontwikkeling van de socialistische vakbeweging leggen.

\section{De structurele ontwikkeling van de socialistische vakbeweging}

\section{Centralisatie en concentratie}

Hoewel de SK, opgericht in 1898 in de schoot van de Belgische Werkliedenpartij (BWP), onder meer de bedoeling had de syndicale centralisering aan te moedigen, blijft het wachten tot na 1907 vooraleer de eerste daadwerkelijke aanzetten daartoe gebeuren.

Daarvóór was het samenbrengen van de afzonderlijke vakbonden in federaties een eerste stap in het unificatieproces van de vakbondsstructuren. Ontoereikend weliswaar ${ }^{(18)}$. Vandervelde licht toe: "C'était un premier pas, une étape nécessaire, dans le sens de la concentration syndicale. Mais ces liens fédératifs restaient assez lâches. On était loin encore du syndicalisme centralisé, du système des Centrales syndicales, qui était en train de faire ses preuves en Allemag- 
$n e^{\prime(19)}$. Naar het Duitse voorbeeld was de syndicale centralisatie de logische volgende stap in het unificatieproces. Vooral de linkervleugel binnen de socialistische vakbeweging stimuleerde deze tendens om op die manier een tegengewicht tegen het opportunisme en het parlementarisme in de BWP te vormen.

Aan de vooravond van de eerste wereldbrand wijzigde de SK haar statuten waarbij ze in het vervolg nog enkel nationale centrales en federaties aanvaardde. Door in 1919 een administratieve reorganisatie door te voeren, versterkte ze haar autoriteit. Voortaan kon ze ook rekenen op een grotere bijdrage van de nationale vakbondsorganisaties en de mogelijkheid om nationale propagandisten aan te stellen. De linkerzijde in de SK had ondertussen haar reserves tegenover het parlementarisme opgeheven en pleitte binnen de BWP telkens weer voor regeringsdeelname.

Tabel 1 - Indicatoren van de structurele ontwikkeling bij de SK / BVV, 1914-1937

\begin{tabular}{|l|r|r|r|r|r|r|r|}
\hline & \multicolumn{7}{|c|}{ Aantal (nationale) federaties / centrales } \\
\cline { 2 - 9 } & 1914 & 1919 & 1920 & 1925 & 1930 & 1935 & 1937 \\
\hline$<=100$ & 10 & 1 & 1 & 1 & 2 & 2 & 1 \\
\hline $101-1.000$ & 15 & 3 & 6 & 2 & 2 & 2 & 2 \\
\hline $1.001-2.500$ & 8 & 6 & 4 & 3 & 1 & 1 & 2 \\
\hline $2.501-5.000$ & 7 & 1 & 2 & 4 & 4 & 4 & 3 \\
\hline $5.001-10.000$ & 3 & 5 & 8 & 7 & 5 & 3 & 4 \\
\hline $10.001-25.000$ & 2 & 5 & 2 & 5 & 5 & 5 & 5 \\
\hline $25.001-50.000$ & 1 & 2 & 2 & 0 & 0 & 2 & 3 \\
\hline $50.001-100.000$ & 0 & 2 & 2 & 4 & 5 & 2 & 1 \\
\hline$>100.001$ & 0 & 2 & 3 & 1 & 0 & 2 & 2 \\
\hline Totaal & 46 & 27 & 30 & 27 & 24 & 23 & 23 \\
\hline
\end{tabular}

\begin{tabular}{|l|r|r|r|r|r|r|}
\hline & \multicolumn{7}{|c|}{ Aandeel lidmaatschap (\%) } \\
\cline { 2 - 7 } & 1919 & $\mathbf{1 9 2 0}$ & $\mathbf{1 9 2 5}$ & $\mathbf{1 9 3 0}$ & $\mathbf{1 9 3 5}$ & $\mathbf{1 9 3 7}$ \\
\hline$<=100$ & 0,01 & 0,01 & 0,01 & 0,02 & 0,04 & 0,02 \\
\hline $101-1.000$ & 0,40 & 0,54 & 0,31 & 0,33 & 0,22 & 0,09 \\
\hline $1.001-2.500$ & 1,64 & 0,87 & 0,81 & 0,27 & 0,30 & 0,79 \\
\hline $2.501-5.000$ & 0,78 & 0,76 & 2,42 & 3,01 & 2,98 & 2,32 \\
\hline $5.001-10.000$ & 5,97 & 9,34 & 9,42 & 6,88 & 3,82 & 4,97 \\
\hline $10.001-25.000$ & 13,81 & 3,28 & 16,17 & 16,79 & 13,45 & 14,23 \\
\hline $25.001-50.000$ & 14,45 & 7,64 & 0,00 & 0,00 & 13,22 & 22,25 \\
\hline $50.001-100.000$ & 22,88 & 21,99 & 50,64 & 72,71 & $\mathbf{4 3 , 8 5}$ & 11,84 \\
\hline$>100.001$ & 40,05 & 55,58 & 20,21 & 0,00 & 22,12 & 43,51 \\
\hline Totaal & $\mathbf{9 9 , 9 9}$ & 100,01 & $\mathbf{9 9 , 9 9}$ & $\mathbf{1 0 0 , 0 1}$ & $\mathbf{1 0 0}$ & $\mathbf{1 0 0 , 0 2}$ \\
\hline
\end{tabular}

Bron: congresverslagen van de SK (1919-36) en het BVV (1937). Registratiebasis- en moment: vierde kwartaalbijdrage (uitgezonderd 1919: tweede kwartaalbijdrage). Eigen berekening 


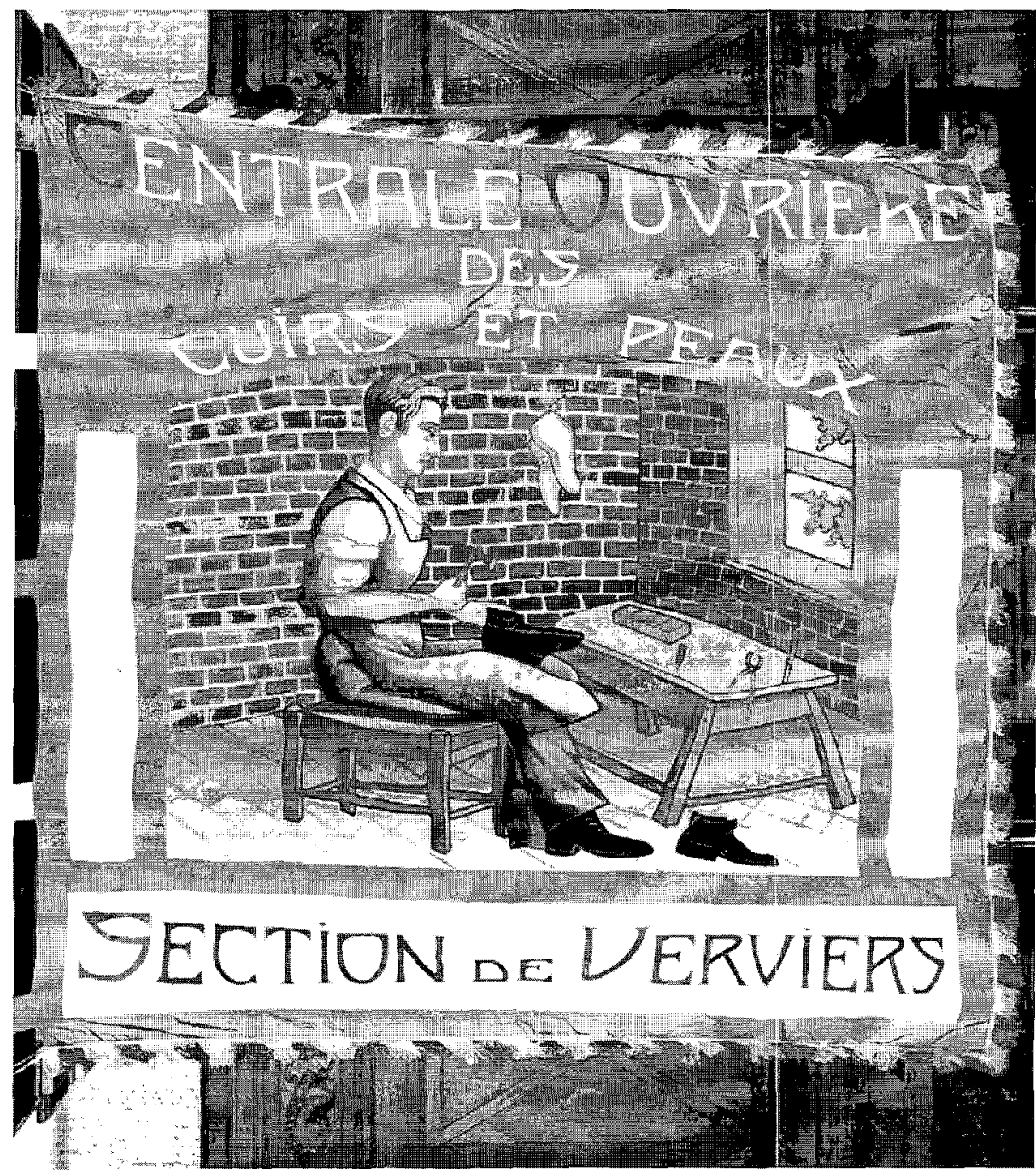

Vlag van de Centrale der Leder- en Vellenbewerkers van Verviers, ongedateerd 
De centralisatiebeweging, die zich na de Eerste Wereldoorlog voltrok, ging gepaard met een fusiegolf tussen de verschillende centrales en resterende federaties (tabel 1, p. 15) en markeerde de overgang van de loutere beroepsvakbonden naar ware industrievakbonden. De SK spoorde daarbij haar nationale centrales sterk aan: "We hopen dat men dat toch eindelijk zal begrijpen dat het stelsel dat bestaat in de groepeering, in de vereeniging aller bestanddeelen die iets gemeens hebben oneindig hooger staat dan het stelsel van het verleden (...) verouderd uit hoofde der hervormingen die in alle domeinen plaats vonden"(20).

\section{Fusies}

De eigenlijke tussenoorlogse concentratiegolf startte op 16 maart 1919 in de kledingnijverheid. Op die datum beslisten de Pels- en Witgoedwerkers, alsook de groep der Ververs-Ontvlekkers van Brussel, tot de oprichting van de Centrale der Kleeding. De Schoen- en Lederbewerkers, de latere Centrale der Ledernijverheid, traden niet toe omdat ze 'juist in een zeer moeilijk oogenblik' verkeerden. De Kleermakers-Snijders stelden hun toetreding tot de Centrale der Kleeding eventjes uit tot 29 augustus. Verder namen ook de Hoedenmakers een afwachtende houding aan, maar sloten zich uiteindelijk op één december 1920 bij de Centrale der Kleeding aan ${ }^{\{21\}}$. Ook de Federatie van Handschoenwerkers hield nog even de boot af, maar vormde zich wel om tot een centrale op 8 april 1919. Ook de mijnwerkers waren niet langer gegroepeerd in een federatie: op één maart 1919 was de Centrale van Mijnwerkers een feit, maar de regionale afdelingen, geconcentreerd rond de mijnbekkens, behielden een ruime autonomie. Met de oprichting van de Algemeenen Diamantbewerkersbond op 24 en 25 mei 1919 was er ook een nationale organisatie in de diamantnijverheid.

De Centrale van Bouw vormde met de Centrale van Hout de Centrale van Bouw en Hout op 1 januari 1920. Een jaar later fusioneerde de Centrale der Fabrieksarbeiders met de Centrale van Bouw en Hout en vormde daarmee de AC van de SK. De Nationale Federatie der Kasseiers of Stratenmakers sloot zich pas op 1 januari 1936 aan bij de AC. De Federatie der Bedienden nam in 1920 een meer gecentraliseerde structuur aan en vormde zich om tot de Centrale der Bedienden. In 1921 sloot de Centrale der Landarbeiders zich aan bij de Centrale der Voeding die haar naam veranderde in Centrale der Voedings- en Landbouwarbeiders. De Centrale der Handschoennijverheid sloot zich op 1 juli 1921 aan bij de Centrale der Ledernijverheid.

Hoewel de oprichting in 1922 van de Intersyndikale der Openbare Diensten geen samengaan van de verschillende vakbonden in de overheidssector betekende, stond deze nieuwe organisatie in voor de 'studie en samenordening' van de vakbonden binnen deze sector. Dit initiatief leidde tot concrete resultaten op 1 januari 1926, toen het Nationaal Syndikaat van het Departement van Financiën en het Nationaal Syndikaat der Openbare Werken zich bij de Centrale der Openbare Diensten aansloten. In 1923 smolten de Centrale der Steendrukkers en de Centrale der Boekdrukkers samen tot de Centrale der Belgische Boekbewerkers. Eveneens in 1923 besliste de Onafhankelijke Vakbond van het Onderwijzend Personeel in Antwerpen de nationale 
Centrale van het Onderwijzend Personeel te versterken.

De centralisatie binnen de Centrale van Textielarbeiders kreeg in 1924 een nieuwe impuls toen de Socialistische Textielcentrale van België, zetelend te Gent, en de Textielfederatie van Verviers beslisten om tot een 'volledige samentrekking' over te gaan. Binnen de textielnijverheid is er pas van een echte centrale sprake in 1935.

De op 6 september 1925 opgerichte Nationale Federatie der Glasbewerkers slaagde erin om verschillende organisaties te doen samengaan. Na een centralisatie sloten ze zich officieel aan bij de AC op 1 januari 1929. De Centrale van het Hotelpersooneel, in feite een beroepsvakbond, voegde zich op 24 oktober 1929 bij de Centrale der Voeding.

De fusies gingen dikwijls gepaard met meningsverschillen tussen de verschillende vakbonden over de afbakening van hun syndicale grenzen. De SK omschreef deze geschillen als: "Misschien wel een der moeilijkste welke zich in de vakorganisatie voordoen, niet alleen in ons land, maar in al de landen des werelds"(22). Derhalve is er in de verslagen van de SK telkens ruime aandacht voor deze materie. Regelmatig moest ze tussenkomen, maar haar optreden was vrij gering wegens de statutaire beperkingen. Daar kwam echter verandering in toen de SK in 1937 haar naam veranderde in Belgisch Vakverbond (BVV) en enkele statutaire hervormingen doorvoerde waardoor ook de band met de BWP losser werd. Evenwel was de centralisatiedrang reeds begin jaren ' 30 quasi stilgevallen. De meeste centrales bleven argwaan koesteren tegenover de centralisatiepogingen van het BVV.

\section{Aansluitingen}

Vooral in de turbulente jaren na de Eerste Wereldoorlog sloten zich verschillende nationale vakbonden aan: de Centrale der Landarbeiders, opgericht door de SK op 13 juli 1919; de Nationale Federatie der Typografen, de oudste vakbond van België; de Nationale Federatie der Tramagenten, in 1922 omgevormd tot een centrale; en het Syndikaat der Burgerlijke Werklieden van het ministerie van Oorlog in 1919; de Federatie van het Tooneelvak, de Spoorweglui van de 'Nord Belge' en het Nationaal Syndikaat der Openbare Werken in 1920; het Nationaal Syndikaat van het Personeel van het ministerie van Openbare Werken en het Nationaal Syndikaat van het Personeel van het ministerie van Geldwezen in 1922. In de jaren '30 volgen er nog twee aansluitingen: de Vereeniging van Koopvaardijofficieren in 1930 en, na het eerder mislukken van de Centrale van Landarbeiders, de opnieuw opgerichte Centrale van het Personeel der Landbouwuitbatingen in 1937.

Dat de fusie- en aansluitingsgolf vooral begin jaren ' 20 valt is blijkbaar geen toeval. Een zelfde concentratie- en aansluitingsbeweging gebeurde toen ook in Nederland, het Verenigd Koninkrijk en Zweden, aldus Visser en Waddington. De auteurs grijpen terug naar de erkenning van de vakbeweging, de uitbreiding van het sociaal overleg en 'specific periods of economic long cycles' om dit fenomeen te verklaren. Hoewel dit 
natuurlijk uitvoeriger en gefundeerder onderzoek vereist, nemen we aan dat een gelijkaardige verklaring ook voor de Belgische context opgaat.

\section{Propagandavoering, ledenwerving en -behoud}

De fusie- en aansluitingsbeweging leidde niet altijd tot de gewenste resultaten en schiep bovendien nieuwe problemen. De centralisatie in de kledingnijverheid bijvoorbeeld leidde tot ledenverlies in de jaren 1922-24 omdat men, zo opperde Paul Van Maldere, "(...) de propaganda heeft willen organiseeren en de werking der vakorganisatie regelen volgens een te eenvorming plan en methodes die niet aan te passen zijn aan den geestestoestand aller arbeiders der kleeding"(23). Het spreekt evenwel voor zich dat er door schaaleffecten meer (financiële) middelen vrijkwamen om propaganda te voeren. Een ondersteunende rol in de propagandavoering speelden de gewestelijke verbonden, daarin bijgestaan door de SK via het in 1923 opgerichte Gemengd propagandakomiteit. Vanaf 1936 vervulde het Propagandafonds een gelijkaardige functie als dit in 1933 opgedoekte comité.

Klassieke wervingsmiddelen zijn de propaganda via woord en pers, de ledenbladen aan 'onvereenigden', vlugschriften, plakbrieven, manifesten en studiedagen, tentoonstellingen en propagandafilms. Sommige centrales, zoals de CMB, gaven daarenboven premies in natura - zoals sigaretten- en tabaksdozen - voor het ronselen van nieuwe leden. Succesvolle propagandisten zagen hun naam bovendien in het ledenblad, i.c. De Metaalbewerker, prijken. De 'meest afdoende en vruchtbaarste methode' echter om leden te winnen én te behouden was het huisbezock.

De Vlaamse afdelingen van de AC bijvoorbeeld haalden via een bode de ledenbijdragen aan huis op. Volgens verslaggever Paul Fassin verklaart net deze methode waarom het ledenaantal voor Vlaanderen in 1922 zich alleen maar stabiliseert, terwijl het dalende ledental in Wallonië geen toeval is, vermits de leden er hun bijdrage in het volkshuis of aan de 'sektionaris' in de fabriek of het werkhuis betalen. Deze tactiek van ledenwerving toont de invloed van het ACV op de Vlaamse afdelingen van de AC en bij uitbreiding, de SK. Reeds voor de Eerste Wereldoorlog rekruteerde het ACV zijn leden niet alleen in de werkplaats, maar ook "(...) in the home, where they could reach the family as a unit"(24). In het Vade-Mecum voor het thuisbezoek, een bijzonder nummer van het Inlichtingsen documentatieblad, ziet ook de AC het belang daarvan in: "De huisvrouw is zoowel belanghebbend als de werkman, want $z i j$ is de huishoudelijke Minister van Financies, zij heeft een groote invloed op de geestesgesteldheid en op de daden van haar man, en vooral omdat zij meestal beinvloed [sic] wordt door buitenstaanders, de handelaar en de priester"(25). Wellicht kunnen we deze hypothese naar voren schuiven: hoe meer de SK zich geconfronteerd zag met zogenaamde 'alimentaire' vakbondsleden, hoe groter het belang van het (herhaalde) huisbezoek.

Een eerste vereiste om de doeltreffendheid van propaganda na te gaan is het inwinnen van informatie daaromtrent en daarna het opstellen van statistieken. De SK kon het 
syndicale belang ervan niet genoeg benadrukken. Herhaaldelijk liet ze dan ook weten de schaarse gedetailleerde cijfergegevens een jammerlijke zaak te vinden. Vooral vrouwen, jongeren en 'vreemde' arbeidskrachten bleken moeilijker te rekruteren en in perifere economische gebieden zoals Limburg en Luxemburg ging het moeizaam. Niet alleen het werven van nieuwe leden bracht problemen met zich, maar ook het behoud ervan. Naast de onderlinge wedijver in eigen rangen en de concurrentie van liberale en neutrale vakbonden, had de SK vooral met het $\mathrm{ACV}$ af te rekenen. Ook ter linkerzijde van de SK was er een rivaliteit die de CMB er in 1925 toe noopte communistische cellenbouwers uit te sluiten. Vooral het grote ledenverloop, tekenend na 1921, baarde de SK kopzorgen: "Tedereen weet (...) dat wij nog heel wat talrijker zouden zijn indien wij al de nieuwe leden hadden kunnen behouden"(26). Tot welke proporties dit ledenverloop kon leiden, illustreert de Centrale van Transportarbeiders (CTB): terwijl er in de periode 1919-1929, 77.878 nieuwe leden toetreden, treden er 68.146 leden uit. Van Maldere verklaart dit falen door de verschillen in 'syndicaal bewustzijn' "(...) tusschen een arbeider die oprecht gehecht is aan de beginselen van het syndikalisme en die in de vakorganisatie het middel ziet zich los te maken van het voogdijschap van het patronaat, en een ander arbeider die het zich voorstelt als een vaag denkbeeld van onderlingen bijstand (... $)^{\prime \prime(27)}$. Deze kritiek op het 'alimentair' syndicalisme doet denken aan hedendaagse commentaren op vakbondsimmobilisme in tijden van reële en vermeende mondialisering.

\section{$\underline{\text { Reconstructie en analyse van de ledencijfers }}$}

\section{De vierde kwartaalbijdrage als registratiemoment en -basis}

Slechts van twee centrales, de AC en de CMB, kunnen we een volledige alternatieve cijferreeks voor het vierde kwartaal reconstrueren (bijlage 2, tabel 7, p. 29). Voor vijf andere centrales (de diamantbewerkers, de textielarbeiders, de mijnwerkers, de openbare diensten en de CTB) kunnen we dit slechts fragmentarisch. De betaling van achterstallige bijdragen van de $\mathrm{AC}$ aan de SK verklaart het opmerkelijke verschil voor 1921 tussen het SK-cijfer (153.520) en het ledenaantal dat we terugvinden bij de AC zelf (106.694). We merken deze anomalie ook bij de CMB: terwijl er 128.656 leden zijn ingeschreven, blijken er, op basis van 520.898 verkochte zegels, 130.224 betalende leden te zijn in december 1922 . We beperken ons tot deze voorbeelden omdat ze exemplarisch zijn om andermaal an te tonen dat de gemiddelde ledencijfers een solidere basis vormen om de ledenevolutie te beschrijven.

\section{Jaargemiddelden}

Een eerste manier om de jaargemiddelden na te gaan, is het berekenen van de jaargemiddelden uit de SK-verslagen op basis van de vier kwartaalbijdragen (tabel 2, p. 21). We noemen de bekomen cijferreeks een 'referentiereeks' omdat ze uitermate geschikt is om later de geldigheid van onze reconstructie te toetsen. 
Het vergelijken van de SK-verslagen met de verslagen van de centrales (of daarmee gelijkgestelde bronnen) brengt een aantal aberraties aan het licht. De cijferreeksen met betrekking tot het aantal 'ingeschreven' leden zijn inderdaad niet homogeen. Hoewel het gros van de centrales het aantal in december 'ingeschreven' leden aan de SK opgeven, constateren we dat, bijvoorbeeld voor de CMB, de jaren 1924 en 1925 betrekking hebben op het vierde kwartaal en de jaren 1927, 1928, 1929, 1931 en 1934 op het jaargemiddelde. Dit is een bijkomend argument om de cijferreeks op basis van de 'ingeschreven' leden te laten vallen. Doch ook aan de waarde van de ledenaantallen voor het vierde kwartaal in de SK-verslagen valt soms te twijfelen. Voor diverse centrales gaat het vrijwel telkens om dezelfde ledenaantallen voor de vier kwartalen. Wellicht gaat het ook om een vast bedrag dat een aantal centrales betaalden aan de SK of om een jaargemiddelde netjes verspreid over de vier kwartalen. De ledencijfers voor het vierde kwartaal hebben met andere woorden niet altijd effectief betrekking op dit kwartaal.

Daarmee rekening houdend én op basis van methodologische inzichten is het dus meer verantwoord ons opnieuw op de verslagen van de centrales zelf te beroepen (bijlage 2, tabel 8, p. 30 en bijlage 3, p. 31). Niettemin halen we voor een aantal centrales de ontbrekende jaargemiddelden uit de SK-verslagen. Voor de periode 1920-37 kunnen we gemiddeld $36,56 \%$ van de ledenaantallen niet vervangen door cijfers uit de verslagen van de centrales zelf. We bekomen dit gemiddelde als volgt. Indien we het jaargemiddelde van een bepaàlde centrale niet in haar verslag terugvinden, nemen we dit uit het SK-verslag. De.som van de jaargemiddelden van alle centrales, gebaseerd op het SKverslag, delen we door het totale jaargemiddelde. De bron voor dit laatste getal is uiteraard ook het SK-verslag. Zo bekomen we per jaar het percentage leden dat we niet kunnen vervangen. Van de inverse hiervan, of het percentage leden per jaar gehaald uit de verslagen van centrales, biedt tabel 2 een overzicht.

Tabel 2 - Aandeel ledencijfers uit centrales (\%) en jaargemiddelde uit SK-verslagen, 1920-37

\begin{tabular}{|c|c|c|c|c|c|c|c|c|}
\hline 1920 & 1921 & 1922 & 1923 & 1924 & 1925 & 1926 & 1927 & 1928 \\
\hline $\begin{array}{c}45,54 \\
(668.856)\end{array}$ & $\begin{array}{c}59,48 \\
(661.776)\end{array}$ & $\begin{array}{c}61,20 \\
(591.798)\end{array}$ & $\begin{array}{c}63,69 \\
(558.988)\end{array}$ & $\begin{array}{c}51,54 \\
(545.731)\end{array}$ & $\begin{array}{c}57,74 \\
(519.468)\end{array}$ & $\begin{array}{c}57,74 \\
(514.906)\end{array}$ & $\begin{array}{c}70,74 \\
(512.424)\end{array}$ & $\begin{array}{c}72,98 \\
(491.711)\end{array}$ \\
\hline 1929 & 1930 & 1931 & 1932 & 1933 & 1934 & 1935 & 1936 & 1937 \\
\hline $\begin{array}{c}73.90 \\
(498.305)\end{array}$ & $\begin{array}{c}85,70 \\
(502.355)\end{array}$ & $\begin{array}{c}78,85 \\
(516.517)\end{array}$ & $\begin{array}{c}50,81 \\
(555.839)\end{array}$ & $\begin{array}{c}63,35 \\
(596.764)\end{array}$ & $\begin{array}{c}63,83 \\
(571.756)\end{array}$ & $\begin{array}{c}63,86 \\
(537.879)\end{array}$ & $\begin{array}{c}76,43 \\
(527.790)\end{array}$ & $\begin{array}{c}54,56 \\
(546.470)\end{array}$ \\
\hline
\end{tabular}

Bron: bijlage 3 en 4; SK-congresverslagen (1921-37) en BW-congresverslag (1938).

Eigen berekening. Gemiddelde: $64,44 \%$ (551.074)

Voor de periode 1920-37 slagen we er dus in om gemiddeld bijna twee derde van onze nieuwe cijferreeks samen te stellen uit de jaargemiddelden uit de verslagen van de centrales zelf. Met uitzondering van 1920 (46\%) maken deze gemiddelden steeds de 


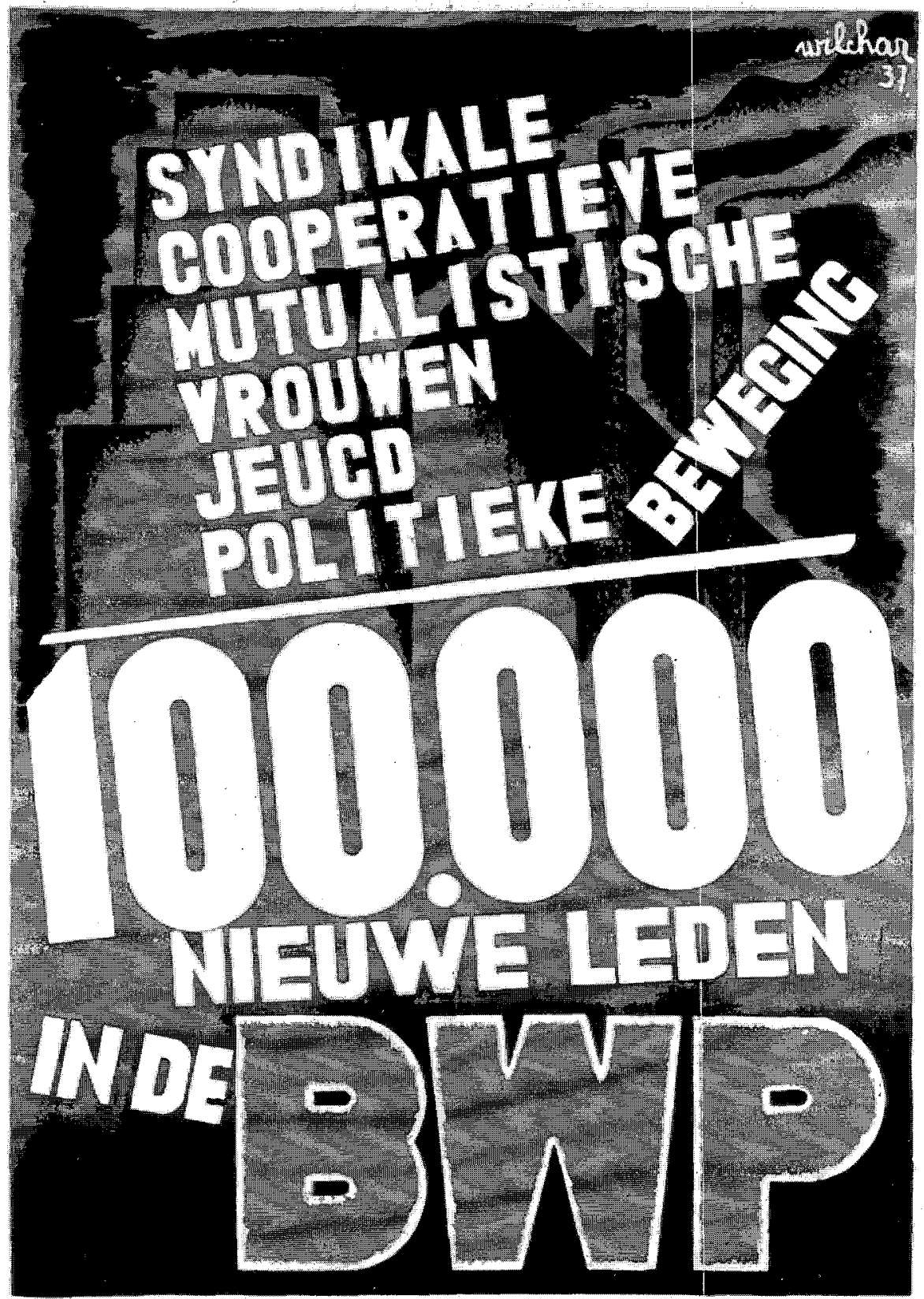

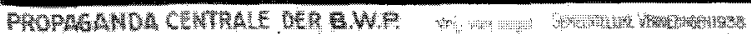

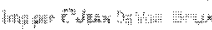

In oktober 1937 zette de BWP een wervingscampagne voor 100.000 nieuue leden op touw 
helft of meer uit - met een piek in 1930 (86\%) - van de gereconstrueerde cijferreeks. De nieuwe cijferreeks voor de jaren 1920-37 is aldus primair gebaseerd op de centrales zelf. Welke geldigheid heeft dit cijferwerk nu?

\section{Validiteit van de reconstructie}

Aan de hand van het eenvoudig basisconcept 'registratiebasis en -moment' recapituleren we eerst nog even kort onze argumentatie. De cijferreeks op basis van het aantal 'ingeschreven' leden vervalt wegens de eerder frauduleuze registratiebasis en het heterogene karakter van het registratiemoment. Hoewel we het vierde kwartaal als registratiebasis van de cijfers niet in twijfel trekken, plaatsen we vraagtekens bij de opportuniteit van het registratiemoment. Zaken zoals achterstallige bijdragen van de nationale vakbondsorganisaties aan de SK, vertekenen de ledenaantallen. Resteren ons nog de jaargemiddelden die qua basis en moment van registratie geen problemen opleveren. Eén reeks, de referentiereeks, baseert zich uitsluitend op de SK-verslagen (tabel 2). Onze uiteindelijke reconstructie maakt hiervan gebruik, maar steunt voornamelijk op de verslagen van de centrales zelf. We geven de voorkeur aan deze laatste reeks omdat de nationale vakbondsorganisaties nu eenmaal de spil zijn van de vakbondsorganisatie.

In de periode 1920-37 ligt de nieuwe cijferreeks gemiddeld 5,11\% onder de reeks gebaseerd op de 'ingeschreven leden'. Tussen deze laatste reeks en onze reconstructie ligt het grootste verschil in 1920 (7,44\%) en het kleinste in 1934 (1,46\%). De reeks op basis van het vierde kwartaal ligt 4,52\% lager en de ledenaantallen gebaseerd op de jaargemiddelden $5,50 \%$. Wat brengt dit cijferfetisjisme ons nu bij? Primo, het bekrachtigt de hypothese dat niet álle vakbondsorganisaties hun 'passieve' leden raamden. Aangezien we eerder schattingen tot $10 \%$ in de verslagen van de centrales aantroffen, zou het verschil tussen de reeks op basis van de 'ingeschreven leden' en de andere cijferreeksen hoger moeten zijn om de stelling te bevestigen dat alle centrales een afgesproken percentage hanteerden. De nationale vakbondsorganisaties schatten met andere woorden gemiddeld het aantal passieve leden minimaal op 4,52\% en maximaal op $5,50 \%$. Onze reconstructie bevindt zich daartussen. Secundo, niet toevallig toont de reeks op basis van het vierde kwartaal het kleinste verschil met de reeks op basis van de 'ingeschreven leden'. We schatten namelijk al eerder in dat de vierde kwartaalcijfers incidentele uitschuivers vertonen. Tertio, de verschillen tussen de absolute waarden van onze reconstructie en de referentiereeks zijn miniem. Overigens is er geen enkele aanwijzing dat de absolute verschillen verband houden met het (wisselend) percentage leden dat we terugvinden in de verslagen van de centrales zelf. Wel hebben de jaargemiddelden uit de verslagen van de centrales de neiging hoger te liggen dan de jaargemiddelden uit de SK-verslagen. Tot slot wijkt onze reconstructie voor de periode 1920-37 trendmatig niet noemenswaardig af van de andere reeksen (tabel 3). 
Tabel 3 - Correlatie tussen verschillende cijferreeksen

\begin{tabular}{|l|c|c|c|c|c|c|c|}
\hline & $\begin{array}{l}\text { 'Inge- } \\
\text { schreven' }\end{array}$ & $\begin{array}{l}\text { Vierde } \\
\text { kwartaal }\end{array}$ & $\begin{array}{l}\text { Vander- } \\
\text { velde }\end{array}$ & Bondas & Neuville & $\begin{array}{l}\text { Refe- } \\
\text { rentie }\end{array}$ & $\begin{array}{l}\text { Recon- } \\
\text { structie }\end{array}$ \\
\hline 'Ingeschreven' & 1,00 & & & & & & \\
\hline Vierde kwartaal & 0,98 & 1,00 & & & & & \\
\hline Vandervelde & 1,00 & 0,98 & 1,00 & & & & \\
\hline Bondas & 0,95 & 0,98 & 0,97 & 1,00 & & & \\
\hline Neuville & 0,96 & 0,97 & 0,96 & 0,96 & 1,00 & & \\
\hline Referentie & 0,98 & 0,98 & 0,99 & 0,97 & 0,98 & 1,00 & \\
\hline Reconstructie & 0,98 & 0,98 & 1,00 & 0,96 & 0,98 & 0,99 & 1,00 \\
\hline
\end{tabular}

Bron: tabel 2,5 en 6 . Eigen berekening

\section{Drie afwijkende jaren}

Er blijven nog twee problemen. Ten eerste zou een jaargemiddelde van 1919 een totaal vertekend beeld geven van de reële machtspositie van de socialistische vakbeweging. Ook verhinderde de onmiddellijke nasleep van de oorlog de uitbouw van een gedegen ledenadministratie. Het SK-verslag voor 1919 biedt geen soelaas: het vermeldt slechts de ledenaantallen voor het vierde kwartaal. We opteren evenwel voor deze laatste cijfers, maar brengen een aantal 'correcties' aan (tabel 4). Voor de diamantbewerkers, de CMB en de Centrale der Openbare diensten kunnen we immers de ledencijfers voor het vierde kwartaal opdiepen uit de verslagen van deze centrales (of daarmee gelijkgestelde bronnen).

Ten tweede moeten we bij gebrek aan bronnen ook afzien van de hierboven beschreven methode voor de jaren 1938 en 1939. We nemen de cijfers van Bondas over (bijlage 1, p. $28)^{(28)}$. Maar voor we de globale ledenevolutie beschrijven, focussen we nog even op enkele frappante ontwikkelingen binnen een aantal centrales.

Tabel 4 - 'Correcties' voor enkele centrales in 1919

\begin{tabular}{|c|c|c|c|}
\hline Centrale & $\begin{array}{l}\text { Leden- } \\
\text { aantal }\end{array}$ & Bron & Opmerking \\
\hline Diamant & 12.846 & $\begin{array}{l}\text { De diamantbe- } \\
\text { werker, nr. 24-27, } \\
29-33(1919) \\
\text { nr. } 34(1920)\end{array}$ & $\begin{array}{l}\text { Eigen berekening. Het vierde kwartaalgemiddelde } \\
((12.700+12.746+12.810+12.985+12.956+ \\
12.948+12.989+12.982+12.958+12.764+ \\
12.712+12.705+12.740 \text { leden }) / 13 \text { weken }) \\
\text { geeft } 12.846 \text { betalen de leden. Zowel het } \\
\text { 'meegedeelde' ledenaantal, als het ledencijfer } \\
\text { voor het vierde kwartaal in het SK-verslag hebben } \\
\text { betrekking op } 3 \text { januari } 1920 \text {. }\end{array}$ \\
\hline CMB & 97.431 & $\begin{array}{l}\text { CMB, Verslag } \\
\text { (1922). }\end{array}$ & $\begin{array}{l}\text { Eigen berekening. Het vierde kwartaalgemiddelde } \\
((400.464+398.382+467.756 \text { zegels }) / 13 \\
\text { weken) geeft } 97.431 \text { betalende leden. }\end{array}$ \\
\hline $\begin{array}{l}\text { Openbare } \\
\text { Dienst }\end{array}$ & 10.981 & $\begin{array}{l}\text { De Belgische } \\
\text { vakbeweging. } \\
16,31 \text { jul. } 1926 .\end{array}$ & \\
\hline
\end{tabular}




\section{Evolutie van de ledenaantallen}

\section{Interne verhoudingen}

Wat onmiddellijk in het oog springt is het slinkende aandeel van de Centrale der Mijnwerkers. Zij verliest meer dan de helft, zo'n 14\%, van haar aandeel in het totale ledenaantal in de periode 1919-37. Ook het Nationaal Syndikaat der Spoor, PTT, Zeeen Luchtvaartwezen (S.P.T.T.Z.L.) vertoont, enkele bokkensprongen daargelaten, een neerwaartse trend: het aandeel krimpt van bijna $14 \%$ naar minder dan $8 \%$ in 1937. Een vrij grote stabiliteit vertoont de CMB: het aandeel schommelt rond één vijfde van het globale ledencijfer. De Centrale der Textielbewerkers daarentegen heeft een wisselend verloop: een snelle opmars tot 1931, maar een dalend aandeel erna. Onder andere als gevolg van haar structurele ontwikkeling kent de AC een stijgend aandeel: in 1937 bedraagt dit meer dan één vijfde. Wellicht stijgt het aandeel van het Algemeen Bediendensyndicaat het spectaculairst: zowaar een verdubbeling in de periode $1930-37$. Toch blijft de sector 'arbeiders' gedurende het interbellum steeds 80 tot $85 \%$ van de SK uitmaken. Het aandeel van de sector 'overheidspersoneel' daarentegen boet in ten voordele van de bediendensector. We geven tot slot nog een kort overzicht van de algemene ledenontwikkeling (tabel 5).

Tabel 5 - Ledencijfers en groeivoeten van de socialistische vakbeweging, 1919-40 (basisjaar 1929)

\begin{tabular}{|c|c|c|c|c|c|c|c|}
\hline 1919 & 1920 & 1921 & 1922 & 1923 & 1924 & 1925 & 1926 \\
\hline $\begin{array}{l}565.913 \\
(112,20)\end{array}$ & $\begin{array}{l}664.957 \\
(131,83)\end{array}$ & $\begin{array}{l}663.961 \\
(131,63)\end{array}$ & $\begin{array}{l}589.352 \\
(116,84)\end{array}$ & $\begin{array}{l}555.580 \\
(110,15)\end{array}$ & $\begin{array}{l}546.731 \\
(108,39)\end{array}$ & $\begin{array}{l}519.478 \\
(102,99)\end{array}$ & $\begin{array}{l}521.380 \\
(103,37)\end{array}$ \\
\hline 1927 & 1928 & 1929 & 1930 & 1931 & 1932 & 1933 & 1934 \\
\hline $\begin{array}{c}502.946 \\
(99,71)\end{array}$ & $\begin{array}{c}496.169 \\
(98,37)\end{array}$ & $\begin{array}{c}504.400 \\
(100)\end{array}$ & $\begin{array}{l}508.766 \\
(100,87)\end{array}$ & $\begin{array}{l}530.224 \\
(105,12)\end{array}$ & $\begin{array}{l}568.465 \\
(112,70)\end{array}$ & $\begin{array}{l}601.229 \\
(119,20)\end{array}$ & $\begin{array}{l}571.587 \\
(113,32)\end{array}$ \\
\hline 1935 & 1936 & 1937 & 1938 & 1939 & 1940 & & \\
\hline $\begin{array}{l}537.097 \\
(106,48)\end{array}$ & $\begin{array}{l}532.120 \\
(105,50)\end{array}$ & $\begin{array}{l}545.419 \\
(108,13)\end{array}$ & $\begin{array}{l}581.951 \\
(115,37)\end{array}$ & $\begin{array}{l}546.224 \\
(108,29)\end{array}$ & $?$ & & \\
\hline
\end{tabular}

Bron: 1919-37: tabel 4 en bijlage 4; 1938-39: bijlage 1. Eigen berekening. Gemiddelde: 554.950

\section{Globaal}

In de woelige periode onmiddellijk na de 'Grote Oorlog' kent de socialistische vakbeweging een buitengewone opmars. Niet toevallig is de discrepantie tussen het aantal 'ingeschreven' leden en de 'aanbetalende' leden het grootst in 1919 en verkleint dit 
verschil naderhand. Bij de Centrale van Voeding, bijvoorbeeld, daalt het aantal ingeschreven leden van 10.457 in 1919 tot 9.219 in 1920. Niettemin stijgt het ledencijfer op basis van de aanbetalende leden. Een verklaring voor het dalende antal ingeschreven leden schrijft de Centrale van Voeding toe aan "(...) het feit dat tal van werklieden tot de vakorganisatie waren toegetreden zonder veel te weten welke de daaraan voor hen verbonden verplichtingen zijn ${ }^{\prime \prime 29)}$. De ledenaanwas bereikt zijn toppunt in de jaren 1920 en 1921. Gedurende de periode 1922-28 daalt het ledental fors. 1929 is het scharnierjaar: voor het eerst stijgt het ledenaantal opnieuw. In de jaren ' 30 houdt deze evolutie aan met een hoogtepunt in 1933; het bereikte niveau van 1920 wordt echter niet meer gehaald.

Hoewel we ons tot een louter descriptief overzicht van de evolutie van de socialistische ledenontwikkeling beperken, kunnen we niet omheen het vaak aangehaalde citaat van Vanthemsche dat "(...) de vakbonden groeiden omdat de arbeiders tot de werkloosheidskas toetraden, en niet omgekeerd" (30). De AC is zich bewust van de keerzijde van de medaille: "Wij moeten ons (...) geen illusies maken en er wel rekening mee houden dat, als de crisis een einde zal nemen, wij het ledental niet zullen behouden, omdat onder de duizenden die ons zijn toegestroomd, er toch nog een groot deel zijn die alleen komen om zich te verzekeren tegen de risico's van de werkloosheid"(31). Na 1933 dalen de ledencijfers opnieuw: de aanhoudende economische crisis noodzaakte de regering tot stringenter maatregelen in de werkloosheidsverzekering. De succesvolle stakingen in 1936 vertalen zich in een ledenwinst in 1937. Het BWPcongres van oktober 1937 besliste om een wervingscampagne voor 100.000 nieuwe leden op touw te zetten - de nakende verplichting van de werkloosheidsverzekering werkte inspirerend. Gezien de ledenwinst in 1938 was deze campagne succesvol, al speelde de economische heropleving natuurlijk ook een rol. De nakende oorlogsdreiging verhinderde een verdere ledengroei in 1939.

\section{Besluit}

We zijn deze bijdrage begonnen met het benadrukken van de belabberde staat van de politieke statistiek in België. Kennelijk is dat niets nieuws onder de zon, want al in 1935 schreef Jan Decock - de titel De erbarmelijke toestand der statistieken in Belgï spreekt voor zich - dat "Onbetwistbaar (...) zich in onze statistiekdiensten ten spoedigste een volledige omwerking en herinrichting op [dringt]"(32). Een schoolvoorbeeld daarvan zijn de ontoereikende publicaties omtrent de ledencijfers van de socialistische vakbeweging in het interbellum, die zich ten eerste kenmerken door een vrij geringe toegankelijkheid. De publicaties van Bondas en Neuville dateren namelijk reeds van respectievelijk 1948 en 1959. Ten tweede kunnen we de bestaande ledenreeksen als ronduit verwarrend bestempelen. Niet iedereen kent en maakt het verschil tussen actieve en passieve vakbondsleden op de arbeidsmarkt. Ten derde vertonen sommige ledenreeksen, zoals deze van Bondas, een vooraanstaand vakbondsman, niet toevallig een dubieus karakter. 
Enig opportunisme gluurde hier wellicht om het hoekje. Tenslotte werkt het gebrek aan homogeniteit van deze ledenreeksen de onbetrouwbaarheid ervan in de hand.

Dezelfde kritische bedenkingen gaan ook op voor de ledencijfers die de SK bekendmakkt. Vooral de ledenaantallen gebaseerd op de mededelingen van de centrales typeren zich door een zeker opportunisme. Het onderscheid tussen de passieve en actieve vakbondsleden is er cruciaal. Teneinde deze passieve vakbondsleden in te schatten, voerden sommige centrales het ledenaantal met een tiende op. Deze praktijk was geen structurele kunstgreep, maar ze vergemakkelijkte eerder de toepassing van de latere correctiecoëfficiënt (of nam scrupules weg). Dit is een belangrijke vaststelling aangezien het ABVV, net zoals de andere representatieve vakbonden, deze aanzienlijke "correctiecoëfficiënt' - ongeveer $15 \%$ - tot op heden stelselmatig blijft toepassen. Tot slot zijn de ledencijfers op basis van het vierde kwartaal geschikter dan de ledenaantallen op basis van de mededelingen, maar (vooral) de betaling van achterstallige bijdragen op het einde van het jaar betekent telkens een artificiële toename van het ledental.

We berekenden een alternatieve cijferreeks die gemiddeld voor zowat twee derden samengesteld is uit ledencijfers afkomstig uit de verslagen van centrales. De structurele ontwikkeling van de socialistische vakbeweging maakte het immers opportuun om de nationale vakbondsorganisatie als eenheid van analyse en observatie te hanteren. Op basis van methodologische beschouwingen becijferden we de jaargemiddelden enkel gebaseerd op de betalende vakbondsleden. We zien geen redenen om hard te twijfelen aan de validiteit van de reconstructie, vermits deze nauwelijks trendmatig verschilt van voorgaande cijferreeksen. Door het feit dat in het interbellum het collectief lidmaatschap nog van kracht was, plaatst onze reconstructie ultima ratio de verhouding tussen de SK en de BWP in een (lichtjes) gewijzigd perspectief. Tenslotte nog dit: uiteraard zijn 'exacte' ledenaantallen niet te achterhalen, maar er is nu minstens enige conceptuele duidelijkheid omtrent de ledencijfers van de socialistische vakbeweging in het interbellum.

Deze bijdrage is een 'bijproduct' van ons doctoraatsonderzoek naar een verklaring voor de omvang en evolutie van de Belgische syndicalisatiegraad. 


\section{BIJLAGE 1}

Tabel 6 - Aantal socialistische vakbondsleden in verschillende bronnen, 1919-1939

\begin{tabular}{|c|c|c|c|c|c|c|}
\hline Jaartal & 'Ingeschreven' & $\begin{array}{l}\text { Vierde } \\
\text { kwartaal }\end{array}$ & $\begin{array}{l}\text { Verschil } \\
\text { 'ingeschreven' } \\
\text { en vierde } \\
\text { kwartaal }\end{array}$ & Vandervelde & Bondas & Neuville \\
\hline 1919 & 629.736 & 576.890 & 52.846 & 629.736 & 576.890 & 563.711 \\
\hline 1920 & 718.410 & 687.610 & 30.800 & 718.410 & 687.610 & 718.410 \\
\hline 1921 & 698.084 & 689.236 & 8.848 & 698.340 & 689.236 & 698.084 \\
\hline 1922 & $618: 871$ & 580.545 & 38.326 & 618.871 & 580.545 & 618.871 \\
\hline 1923 & 594.998 & 568.715 & 26.283 & 594.998 & 568.715 & 594.998 \\
\hline 1924 & 577.885 & 549.376 & 28.509 & 577.885 & 549.715 & 577.885 \\
\hline 1925 & 552.094 & 525.039 & 27.055 & 552.094 & 525.039 & 552.094 \\
\hline 1926 & 551.860 & 526.221 & 25.639 & 551.860 & 526.221 & 551.860 \\
\hline 1927 & 530.575 & 518.000 & 12.575 & 530.575 & 530.575 & 530.575 \\
\hline 1928 & 518.658 & 494.124 & 24.534 & 518.638 & 518.658 & 518.625 \\
\hline 1929 & 528.380 & 504.605 & 23.775 & 528.380 & 504.605 & 534.269 \\
\hline 1930 & 537.379 & 502.781 & 34.598 & 537.379 & 502.781 & 537.379 \\
\hline 1931 & 559.910 & 522.476 & 37.434 & 559.910 & 522.476 & 559.910 \\
\hline 1932 & 608.579 & 572.171 & 36.408 & 608.579 & 572.171 & 608.579 \\
\hline 1933 & 629.532 & 591.976 & 37.556 & 629.532 & 591.976 & 629.442 \\
\hline 1934 & 580.074 & 558.812 & 21.262 & - & 580.074 & 580.074 \\
\hline 1935 & 545.119 & 538.442 & 6.677 & - & 545.119 & 545.119 \\
\hline 1936 & 573.839 & 542.519 & 31.320 & - & 573.839 & 570.839 \\
\hline 1937 & 572.224 & 549.182 & 23.042 & - & 546.469 & 572.224 \\
\hline 1938 & - & - & - & - & 581.951 & - \\
\hline 1939 & - & - & - & - & 546.224 & - \\
\hline Gemiddelde & 585.590 & 557.827 & 27.763 & 590.346 & 562.900 & 582.260 \\
\hline
\end{tabular}

Bron: kolom 2 en 3: SK-congresverslagen (1921-37) en BVV-congresverslag (1938); kolom 4: E. VANDERVELDE (1936), pp. 250-251; kolom 5: J. BONDAS (1948), p. 413 en p. 467; kolom 6: J. NEUVILLE (1959), p. 152. Annexe 8. Eigen berekeningen. Voor twee jaren vinden we nog andere ciffers terug: 698.384 leden in 1921 volgens C. MERTENS (1925), p. 32 en 457.992 leden in 1930 volgens G. SPITAELS (1967), p. 32. Het eerste cijfer is wellicht een drukfout en het laatste cijfer slaat op de gewestelijke verbonden 


\section{BIJLAGE 2}

Tabel 7 - De vierde kwartaalbijdrage bij de AC, de CMB en de SK, 1919-1937

\begin{tabular}{|c|c|c|c|c|c|c|}
\hline & \multicolumn{3}{|c|}{$A C$} & \multicolumn{3}{|c|}{ CMB } \\
\hline & $\begin{array}{l}\text { '31 dec' } \\
\text { (SK) }\end{array}$ & $\begin{array}{c}\text { 4de Kwartaal } \\
\text { (SK) }\end{array}$ & $\begin{array}{l}\text { 4de Kwartaal } \\
\text { (AC) }\end{array}$ & $\begin{array}{c}\text { '31 dec' } \\
\text { (SK) }\end{array}$ & $\begin{array}{c}\text { 4de Kwartaal } \\
\text { (SK) }\end{array}$ & $\begin{array}{c}\text { 4de Kwartaal } \\
\text { (CMB) }\end{array}$ \\
\hline 1919 & - & - & - & 116.300 & 107.595 & 97.431 \\
\hline 1920 & - & - & - & 163.360 & 141.184 & 139.057 \\
\hline 1921 & 137.500 & 153.520 & 106.694 & 138.042 & 129.773 & 129.369 \\
\hline 1922 & 102.870 & 85.797 & 102.870 & 128.656 & 113.688 & 113.511 \\
\hline 1923 & 96.146 & 92.584 & 96.146 & 113.831 & 113.769 & 113.831 \\
\hline 1924 & 85.842 & 84.115 & 87.424 & 115.707 & 115.700 & 115.707 \\
\hline 1925 & 80.543 & 80.543 & 81.580 & 106.122 & 106.123 & 106.122 \\
\hline 1926 & 75.930 & 74.978 & 75.783 & 100.215 & 104.338 & 104.369 \\
\hline 1927 & 71.960 & 71.960 & 72.103 & 95.990 & 99.801 & 99.801 \\
\hline 1928 & 68.016 & 72.556 & 71.178 & 96.477 & 96.383 & 105.315 \\
\hline 1929 & 79.279 & 76.829 & 80.964 & 100.106 & 103.164 & 106.791 \\
\hline 1930 & 89.002 & 83.828 & 83.688 & 102.350 & 96.507 & 101.904 \\
\hline 1931 & 96.710 & 91.080 & 96.803 & 102.010 & 101.063 & 104.076 \\
\hline 1932 & 107.102 & 110.096 & 118.607 & 119.492 & 111.222 & 118.513 \\
\hline 1933 & 127.581 & 124.687 & 127.581 & 129.646 & 114.605 & 120.546 \\
\hline 1934 & 126.544 & 122.444 & 126.544 & 113.656 & 108.461 & 120.536 \\
\hline 1935 & 120.065 & 125.649 & 120.004 & 111.251 & 110.452 & 110.035 \\
\hline 1936 & 126.937 & 124.324 & 123.505 & 123.947 & 109.712 & 125.139 \\
\hline 1937 & 126.721 & 122.400 & $?$ & 116.450 & 116.527 & 126.260 \\
\hline
\end{tabular}

Bron: kolom 2, 3, 5 en 6: SK-congresverslagen (1921-37) en BVV-congresverslag (1938); kolom 4: eigen berekeningen op basis van AC, Versiagen (1922-37) en Inlichtings- en documentatieblad van de Algemeene Centrale, 71, 9 sept. 1935; kolom 7: eigen berekeningen op basis van CMB, Verslagen (1921-24; 1930-38); De Belgische vakbeweging, 7,28 maart 1925; De Metaalbewerker, 23 maart 1926; De Metaalbewerker, 24 maart 1927; De Metaalbewerker, 25 april 1928 en De Metaalbewerker, 26 april 1929 
Tabel 8 - Het jaargemiddelde bij de AC, de CMB en de SK, 1919-1940

\begin{tabular}{|c|c|c|c|c|c|c|}
\hline & 1919 & 1920 & 1921 & 1922 & 1923 & 1924 \\
\hline AC (SK) & - & - & 112.150 & 98.373 & 92.584 & 85.367 \\
\hline AC & - & - & 114.598 & 98.611 & 92.427 & 87.290 \\
\hline Verschil & - & - & -2.448 & -238 & 157 & -1.923 \\
\hline CMB (SK) & $?$ & 135.355 & 139.014 & 114.303 & 106.295 & 110.360 \\
\hline CMB & 50.275 & 139.413 & 139.016 & 114.303 & 106.295 & 110.360 \\
\hline Verschil & $?$ & -4.058 & -2 & 0 & 0 & 0 \\
\hline
\end{tabular}

\begin{tabular}{|c|c|c|c|c|c|c|}
\hline & 1925 & 1926 & 1927 & 1928 & 1929 & 1930 \\
\hline AC (SK) & 80.543 & 74.978 & 71.960 & 72.556 & 75.004 & 78.753 \\
\hline AC & 80.543 & 75.842 & 71.737 & 71.997 & 77.350 & 80.637 \\
\hline Verschil & 0 & -864 & 223 & 559 & -2.346 & -1.884 \\
\hline CMB (SK) & 104.972 & 100.215 & 96.316 & 95.056 & 99.781 & 97.953 \\
\hline CMB & 104.972 & 100.214 & 95.990 & 96.478 & 100.106 & 96.843 \\
\hline Verschil & 0 & 1 & 326 & -1.422 & -325 & 1.110 \\
\hline
\end{tabular}

\begin{tabular}{|c|c|c|c|c|c|c|}
\hline & 1931 & 1932 & 1933 & 1934 & 1935 & 1936 \\
\hline AC (SK) & 86.170 & 101.788 & 122.561 & 119.714 & 121.094 & 117.412 \\
\hline AC & 89.411 & 109.963 & 125.589 & 121.838 & 120.740 & 118.806 \\
\hline Verschil & -3.241 & -8.175 & -3.028 & -2.124 & 354 & -1.394 \\
\hline CMB (SK) & 100.586 & 108.000 & 116.672 & 112.470 & 106.006 & 107.539 \\
\hline CMB & 102.010 & 111.059 & 118.572 & 113.656 & 107.665 & 111.055 \\
\hline Verschil & -1.424 & -3.059 & -1.900 & -1.186 & -1.659 & -3.516 \\
\hline
\end{tabular}

\begin{tabular}{|c|c|c|c|c|}
\hline & 1937 & 1938 & 1939 & 1940 \\
\hline $\mathrm{AC}(\mathrm{SK})$ & 120.732 & $?$ & $?$ & $?$ \\
\hline $\mathrm{AC}$ & $?$ & $?$ & $?$ & $?$ \\
\hline Verschil & $?$ & $?$ & $?$ & $?$ \\
\hline $\mathrm{CMB}(\mathrm{SK})$ & 116.123 & $?$ & $?$ & $?$ \\
\hline CMB & 116.465 & 117.924 & 113.636 & 80.226 \\
\hline Verschil & -342 & $?$ & $?$ & $?$ \\
\hline
\end{tabular}

Bron: eigen berekening op basis van SK-congresverslagen (1921-37), BVV-congresverslag (1938); AC, Verslagen (1922-37); CMB, Verslagen (1920-39); J. BONDAS (1947), p. 164. Bondas' cijferreeks voor de CMB is wel degelijk betrouwbaar, cf. J. FRANSEN (1990), p. 243 


\section{BIJLAGE 3}

Tabel 9 - Het jaargemiddelde in verschillende centrales

\begin{tabular}{|c|c|c|}
\hline Centrale & Ledencijfers (jaar) & Bron \\
\hline Boekbewerkers & $\begin{array}{l}4.596(1924) ; 4.974(1925) \\
4.784(1926) ; 4.487(1927) \\
4.443(1928) ; 4.607(1929) \\
4.669(1930) ; 4.630(1931) \\
4.501(1932) ; 4.420(1933) \\
4.199(1934) ; 3.980(1936) \\
4.233(1937) ; 4.301(1938)\end{array}$ & $\begin{array}{l}\text { Le travailleur du livre, } 1,2 \text {, fév-nov. } \\
1924 ; \\
\text { Le travailleur du livre, } 2,1 \text {, jan. } 1925 ; \\
\text { Le travailleur du livre, } 2,2 \text {, fév. } 1925 ; \\
\text { Le travailleur du livre, 4, 4, avr. } 1927 ; \\
\text { Le travailleur du livre, } 5,8 \text {, aou. } 1928 ; \\
\text { Le travailleur du livre, } 6,3 \text {, mar. } 1929 ; \\
\text { Le travailleur du livre, } 7,5 \text {, mai } 1930 ; \\
\text { Le travailleur du livre, } 8,8 \text {, aou } 1931 ; \\
\text { Le travailleur du livre, } 9,4 \text {, avr. } 1932 ; \\
\text { Le travailleur du livre, 10, 5, mai } 1933 ; \\
\text { Le travaileur du livre. Numéro spécial. } \\
\text { Octobre } 1935 \text {. Centrale der } \\
\text { Boekbewerkers, Verslagen (1938-40). } \\
\text { Eigen berekening. }\end{array}$ \\
\hline Boekbinders & $\begin{array}{l}1.987(1920) ; 2.519(1921) \\
2.756(1922) ; 2.935(1923)\end{array}$ & $\begin{array}{l}\text { Centrale der Boekbinders, Verslagen } \\
(1922-24) \text {. Eigen berekening. }\end{array}$ \\
\hline Steenbewerkers & $22.764(1923) ; 23.139(1924)$ & $\begin{array}{l}\text { Le carrier, } 27 \text {, aoû. 1925; Centrale der } \\
\text { Steenbewerkers, Verslagen (1925). }\end{array}$ \\
\hline $\begin{array}{l}\text { Onderwijzend } \\
\text { Personeel }\end{array}$ & $3.915(1931)$ & $\begin{array}{l}\text { Centrale Onderwijzend Personeel, } \\
\text { Versiag (1932). Eigen berekening. }\end{array}$ \\
\hline Textielarbeiders & $\begin{array}{l}65.443(1926) ; 69.486(1927) \\
74.273(1928) ; 75.773(1929) ; \\
76.620(1930) ; 84.407(1931) \\
65.138(1936) ; 65.204(1937) \\
65.686(1938)\end{array}$ & $\begin{array}{l}\text { Centrale der Textielarbeiders, Verslagen } \\
\text { (1927-39) en eigen berekening. }\end{array}$ \\
\hline Kleeding & $\begin{array}{l}4.883(1922) ; 4.066(1923) \\
2.486(1929) ; 2.622(1930) \\
2.930(1931) ; 3.482(1932) \\
4.059(1933) ; 3.340(1934) \\
3.001(1935)\end{array}$ & $\begin{array}{l}\text { De Belgische vakbeweging, } 25,6 \text { dec. } \\
\text { 1924; Centrale der Kleeding, Verslagen } \\
\text { (1932); Arbeidsblad november (1934); } \\
\text { De Belgische vakbeweging, } 9,20 \text { sep. } \\
1936 \text { en eigen berekening. }\end{array}$ \\
\hline Lederbewerkers & $\begin{array}{l}8.839(1922) ; 8.621(1923) \\
8.588(1924) ; 8.944(1928) ; \\
8.845(1929) ; 8.645(1930) ; \\
8.518(1931) ; 9.366(1932) ; \\
9.296(1933) ; 8.514(1934) ; \\
7.719(1935) ; 7.738(1936) ; \\
7.910(1937) ; 8.008(1938)\end{array}$ & $\begin{array}{l}\text { Centrale der Lederbewerkers, Verslagen } \\
\text { (1931-39) en eigen berekening. }\end{array}$ \\
\hline $\begin{array}{l}\text { Diamant- } \\
\text { bewerkers }\end{array}$ & $\begin{array}{l}7.858(1920) ; 9.511(1921) ; \\
9.701(1922) ; 10.574(1923) ; \\
11.321(1924) ; 11.843(1925) ; \\
12.920(1926) ; 13.618(1927) ; \\
14.998(1928) ; 14.566(1929) ; \\
12.955(1931) ; 12.249(1932) \text {, } \\
11.893(1933) ; 11.414(1934) ; \\
10.943(1935) ; 11.555(1936) ; \\
12.602(1937) ; 12.154(1938) \text {; }\end{array}$ & $\begin{array}{l}\text { De diamantbewerker (1920-39). Eigen } \\
\text { berekening. }\end{array}$ \\
\hline
\end{tabular}




\section{BIJLAGE 4}

Tabel 10 - De ledenaantallen van de SK, 1919-1928 (reconstructie)

\begin{tabular}{|c|c|c|c|c|c|}
\hline & 1919 & 1920 & 1921 & 1922 & $\begin{array}{r}1923 \\
\end{array}$ \\
\hline Centrale der Boekbewerkers & - & - & - & - & - \\
\hline Centrale der Steendrukkers & 1.017 & 1.108 & 1.073 & 1.151 & 1.390 \\
\hline Centrale der Boekbinders & 2.379 & 1.987 & 2.519 & 2.756 & 2.935 \\
\hline Belgisch Boekdrukkersverbond & 4.499 & 4.858 & 5.385 & 5.754 & 5.800 \\
\hline Algemene Centrale & - & - & 114.598 & 98.611 & 92.427 \\
\hline Centrale van Bouw en Hout & - & 68.340 & & & \\
\hline Centrale van Bouw & 34.840 & & & & \\
\hline Centrale van Hout & 19.000 & & & & \\
\hline Centrale van Gemengde Vakken & 42.642 & 51.383 & & & \\
\hline Nationaal verbond der Glasbewerkers & - & - & - & - & - \\
\hline Centrale van Glasbewerkers & 7.380 & 8.959 & 9.975 & 7.059 & 5.064 \\
\hline Centrale der Magazijniers-Glasbewerkers & 1.000 & 1.050 & 635 & 643 & 720 \\
\hline Centrale der Kasseiers & 1.225 & 1.303 & 1.349 & 1.213 & 1.090 \\
\hline Centrale der Steenbewerkers & 19.996 & 25.300 & 25.752 & 25.050 & 22.764 \\
\hline Algemeen Bediendensyndikaat & 7.900 & $10.250 \mathrm{i}$ & 10.125 & 8.125 & 7.750 \\
\hline Centrale Onderwijzend Personeel & 1.640 & 2.026 & 2.024 & 2.000 & 2.000 \\
\hline Syndikaat der Dagbladschrijvers & 33 & 48 & 54 & 55 & 60 \\
\hline Syndikaat der Geneesheren & - & - & - & - & - \\
\hline Centrale der Textielarbeiders & 40.740 & 52.152 & 65.191 & 62.721 & 61.062 \\
\hline Centrale der Kleeding & 5.679 & 6.357 & 6.048 & 4.883 & 4.066 \\
\hline Vereeniging der Kleermakers-Snijders & 235 & 118 & & & \\
\hline Centrale der Hoedenmakers & 1.150 & 958 & & & \\
\hline Centrale der Lederbewerkers & 6.273 & 7.547 & 8.749 & 8.839 & 8.621 \\
\hline Federatie der Handschoennijverheid & 640 & 807 & 348 & & \\
\hline Centrale der Diamantbewerkers & 12.846 & 7.858 & 9.511 & 9.701 & 10.574 \\
\hline Nationaal verbond der Juweliers & 680 & 740 & 750 & 750 & 750 \\
\hline Centrale der Metaalbewerkers & 97.431 & 139.413 & 139.016 & 114.303 & 106.295 \\
\hline Centrale der Mijnwerkers & 123.468 & 112.964 & 103.580 & 85.874 & 72.374 \\
\hline Centrale der Openbare Diensten & 10.981 & 10.981 & 11.011 & 10.123 & 9.400 \\
\hline Nationaal Syndikaat der Openbare Werken & - & - & - & 2.000 & 2.000 \\
\hline Nationaal Syndikaat der Financiën & - & - & - & 2.579 & 3.750 \\
\hline Nationaal Syndikaat S.P.T.T.Z.L. & 78.152 & 90.013 & 84.670 & 74.445 & 76.871 \\
\hline $\begin{array}{l}\text { Syndikaat Burgerlijk Personeel } \\
\text { Landsverdediging }\end{array}$ & - & 2.117 & 1.430 & 1.319 & 1.268 \\
\hline Centrale der Tabaksbewerkers & 10.171 & 9.000 & 8.750 & 8.125 & 7.750 \\
\hline Centrale der Transportarbeiders & 24.862 & 27.520 & 26.612 & 24.648 & 23.130 \\
\hline $\begin{array}{l}\text { Centrale Tram- en } \\
\text { Buurtspoorwegenpersoneel }\end{array}$ & - & 9.184 & 11.157 & 11.594 & 12.409 \\
\hline Centrale der Voeding & 7.000 & 8.250 & 9.088 & 9.150 & 8.460 \\
\hline
\end{tabular}

Bron: tabel 4 en bijlage 3; SK-congresverslagen(1921-29) 
Tabel 11 - De ledenaantallen van de SK (BVV), 1929-37 (reconstructie)

\begin{tabular}{|c|c|c|c|c|c|}
\hline & 1929 & 1930 & 1931 & 1932 & 1933 \\
\hline Centrale der Boekbewerkers & 4.607 & 4.669 & 4.630 & 4.501 & 4.420 \\
\hline Belgisch Boekdrukkersverbond & 6.389 & 6.430 & 6.384 & 5.994 & 6.042 \\
\hline Algemene Centrale & 77.350 & 80.637 & 89.411 & 109.963 & 125.589 \\
\hline Centrale der Kasseiers & 825 & 835 & 828 & 825 & 825 \\
\hline Centrale der Steenbewerkers & 21.000 & 20.639 & 22.073 & 23.919 & 25.035 \\
\hline Algemeen Bediendensyndikaat & 6.100 & 6.785 & 7.369 & 9.633 & 12.491 \\
\hline Centrale Onderwijzend Personeel & 3.700 & 3.700 & 3.915 & 4.150 & 4.488 \\
\hline Syndikaat der Dagbladschrijvers & 80 & 85 & 92 & 92 & 98 \\
\hline Syndikaat der Geneesheren & 31 & 31 & 33 & 33 & 33 \\
\hline Centrale der Textielarbeiders & 75.773 & 76.620 & 84.407 & 85.000 & 85.000 \\
\hline Centrale der Kleeding & 2.486 & 2.622 & 2.930 & 3.482 & 4.059 \\
\hline Centrale der Hoedenmakers & - & 461 & 500 & 550 & 575 \\
\hline Centrale der Lederbewerkers & 8.845 & 8.645 & 8.518 & 9.366 & 9.296 \\
\hline Centrale der Diamantbewerkers & 14.566 & 14.125 & 12.955 & 12.249 & 11.893 \\
\hline Nationaal verbond der Juweliers & 800 & 800 & 750 & 700 & 700 \\
\hline Centrale der Metaalbewerkers & 100.106 & 96.843 & 102.010 & 111.059 & 118.572 \\
\hline Centrale der Mijnwerkers & 58.245 & 55.566 & 54.096 & 55.719 & 62.015 \\
\hline Centrale der Openbare Diensten & 13.649 & 14.272 & 14.754 & 14.736 & 15.016 \\
\hline Nationaal Syndikaat S.P.T.T.Z.L. & 54.164 & 55.739 & 55.437 & 54.458 & 51.427 \\
\hline Syndikaat Agenten Nord-Belge & - & 4.500 & 4.500 & 4.771 & 4.736 \\
\hline $\begin{array}{l}\text { Syndikaat Burgerlijk Personeel } \\
\text { Landsverdediging }\end{array}$ & 1.122 & 1.284 & $\quad 1.472$ & 1.592 & 1.578 \\
\hline Centrale der Tabaksbewerkers & 5.500 & 5.659 & 5.768 & 5.732 & 5.585 \\
\hline Centrale der Transportarbeiders & 23.469 & 22.443 & 23.536 & 26.132 & 28.198 \\
\hline Unie Koopvaardijofficiëren & - & 228 & 903 & 900 & 900 \\
\hline \begin{tabular}{|l|} 
Centrale Tram-en \\
Buurtspoorwegenpersoneel \\
\end{tabular} & 12.993 & 13.236 & 12.728 & 12.584 & 12.858 \\
\hline Centrale der Voeding & 6.500 & 7.224 & 7.100 & 7.200 & 7.300 \\
\hline Centrale Personeel Landbouwuitbatingen & - & - & - & - & - \\
\hline Centrale van het Hotelpersoneel & 1.100 & & & & \\
\hline $\begin{array}{l}\text { Nationale Federatie van het } \\
\text { Tooneelpersoneel }\end{array}$ & 5.000 & 4.688 & 3.125 & 3.125 & 2.500 \\
\hline Totaal & 504.400 & 508.766 & 530.224 & 568.465 & 601.229 \\
\hline
\end{tabular}


Vervolg tabel 11

\begin{tabular}{|c|c|c|c|c|}
\hline & 1934 & 1935 & 1936 & 1937 \\
\hline Centrale der Boekbe werkers & 4.199 & 3.968 & 3.980 & 4.233 \\
\hline Belgisch Boekdrukkersverbond & 5.704 & 5.577 & 5.361 & 5.356 \\
\hline Algemene Centrale & 121.838 & 120.740 & 118.806 & 120.732 \\
\hline Centrale der Kasseiers & 825 & 686 & & \\
\hline Centrale der Steenbewerkers & 24.570 & 23.113 & 20.879 & 20.830 \\
\hline Algemeen Bediendensyndikaat & 13.517 & 13.570 & 14.092 & 15.806 \\
\hline Centrale Onderwijzend Personeel & 5.000 & 4.125 & 5.300 & 5.400 \\
\hline Syndikaat der Dagbladschrijvers & 100 & 100 & 100 & 100 \\
\hline Syndikaat der Geneesheren & 33 & 70 & 100 & 120 \\
\hline Centrale der Textielarbeiders & 79.500 & 67.500 & 65.138 & 65.204 \\
\hline Centrale der Kleeding & 3.340 & 3.001 & 3.341 & 3.349 \\
\hline Centrale der Hoedenmakers & 600 & 600 & 500 & 600 \\
\hline Centrale der Lederbewerkers & 8.514 & 7.719 & 7.738 & 7.910 \\
\hline Centrale der Diamantbewerkers & 11.414 & 10.943 & 11.555 & 12.602 \\
\hline Nationaal verbond der Juweliers & 600 & 450 & 450 & 438 \\
\hline Centrale der Metaalbewerkers & 113.656 & 107.665 & 111.055 & 116.465 \\
\hline Centrale der Mijnwerkers & 58.094 & 53.695 & 49.595 & 46.701 \\
\hline Centrale der Openbare Diensten & 14.350 & 13.732 & 14.458 & 16.225 \\
\hline Nationaal Syndikaat S.P.T.T.Z.L. & 47.026 & 42.328 & 41.608 & 41.310 \\
\hline Syndikaat Agenten Nord-Belge & 4.417 & 4.031 & 3.875 & 3.732 \\
\hline $\begin{array}{l}\text { Syndikaat Burgerlijk Personeel } \\
\text { Landsverdediging }\end{array}$ & 1.527 & 1.593 & 1.758 & 2.489 \\
\hline Centrale der Tabaksbewerkers & 4.711 & 4.225 & 4.375 & 4.500 \\
\hline Centrale der Transportarbeiders & 26.851 & 26.911 & 27.494 & 29.000 \\
\hline Unie Koopvaardijofficiëren & 900 & 900 & 900 & 900 \\
\hline $\begin{array}{l}\text { Centrale Tram-en } \\
\text { Buurtspoorwegenpersoneel }\end{array}$ & 12.176 & 12.044 & 12.337 & 12.600 \\
\hline Centrale der Voeding & 7.500 & 7.811 & 7.325 & 8.325 \\
\hline Centrale Personeel Landbouwuitbatingen & - & - & - & 492 \\
\hline \multicolumn{5}{|l|}{ Centrale van het Hotelpersoneel } \\
\hline $\begin{array}{l}\text { Nationale Federatie van het } \\
\text { Tooneelpersoneel }\end{array}$ & 625 & & & \\
\hline Totaal & $\mathbf{5 7 1 . 5 8 7}$ & 537.097 & 532.120 & 545.419 \\
\hline
\end{tabular}

Bron: bijlage 3; SK-congresverslagen (1930-37) en BVV-congresverslag (1938) 
(I) W. DEWACHTER, Politieke statistiek in België. Oproep bij het einde van 170 jaar Beigië. In: Res Pub/ica, 42(2000)2-3, p. 380.

(2) B. EBBINGHAUS, I. VISSER, P. PASTURE e.a., Belgium. In: B. EBBINGHAUS, I. VISSER, Trade Lnions in Western Europe since 1945. Oxford: MacMillan, 2000, p. 122.

(3) Visser geciteerd in K. VANDAELE. Oorzaken van de hoge syndicalisaticgraad in België. RUG, scriptie. 19992000, p. 12.

(4) P. HUDSON, History by Numbers. An Introduction to Quantitative Approaches, London: Arnold, 2000, p. XVII.

(5) I. NEUVILLE, Une génération syndicale, Bruxelles: La Pensée catholique, 1959, p. 8; cf. G. VANTHEMSCHE, De werkloosheid in België. 1929-1940. Berchem: EPO. 1989, p. 297.

(6) Op de vraag welke waarde er aan deze ledenciffers moet worden gehecht, antwoordt Neuville: "Ils n'indiquent qu une tendance, et ce serait une erreur d'y chercher une précision qu'il est impossible d'y trouver. Nous avons même abandonné /'idée de trop encombrer les tableaux de noies indiQuant des rectifications de chiffres. Nous navons pas cru bon. dans la même optique, de donner des précisions sur le mode de calcul des effectifs.". 1. NEUVILLE, Une génération /.../. p. 6.

(7) G. VANTHEMSCHE, De werkloosheid /...). p. 298.

(8) De 'logic of membership' definiëren Ebbinghaus en Visser als "how to extract sufficient resources from members by offering voice, representation and benefits". terwijl ze de 'logic of influence' omschrijven als "how to gain recognition and benefits. as well as concessions, from employers or governments through ensuring compliance by members". B. EBBINGHAUS. J. VISSER, A Guide to the Handbook. In: B. EBBINGHAUS, J. VISSER, Trade Unions (.../. p. 19.

(9) |.-I. MESSIAEN, A. MUSICK, De socialistische vakbeweging tijdens het interbellum. in: L. PEIREN, I.-1. MESSIAEN, Een eeuw solidariteit 1898-1998, Brussel: ABW. 1998. p. 58.

(10) AC, Verslag 1922 (1923), pp. 64-65. Zie ook CMB. Verslag 1928-1929 (1930), p. 50; S.P.T.T.L.Z., Verslag 1930-1931 (1932). p. 38: NSBL, Verslag 1926 (1927). p. 7.

(I I) BTB, Verslag 1924-25 (1926), p.12.

(12) SK. Verslag 192/ (1922), p. 4.

(13) SK, Verslag 192/ (1922), p. 159.

(14) In het 'Gentse systeem' subsidieert de overheid de werkloosheidsfondsen van de vakbonden. Aangezien in zo'n systeem meestal alleen de vakbeweging de (doorgaans) facultatieve werkloosheidsverzekering controleert. hebben werklozen er alle belang bij om vakbondslid te worden én te blijven. In de meeste landen kwam een einde aan hel Gentse systeem toen de overheid de werkloosheidsverzekering verplichtte. In een aantal landen, waaronder België, blifft dit systeem, weliswaar in een gewijzigde vorm, bestaan.

(15) P. PASTURE. I. MAMPUYS. In de ban /.../. p. 67.

(16) G. S. BAIN, R. PRICE, Profiles of Union Growth. A Comparative Statistical Portrait of Eight Countries. Oxford: Blackwell Publishers, 1980, p. 5. Pater Scholl schrift hierover: "Die overdrijing der ledenciffers is overigens een probleem op zichzelf in de geschiedenis der katholieke en socialistische arbeidersbewegingen in België." S. H. SCHOLL, 150 jaar katholieke arbeidersbeweging in België (1789-1939). Tweede deel. De christen-democratie (1886-19/4). Brussel: Arbeiderspers. 1965, p. 334, voetnoot 145.

(17) R. EBERTZHEIM, Les syndicats ouvriers en Belgique, Luik: Bibliothèque de l'École supérieure de sciences commerciales et économiques de l'Université de liège, 34. 1959. p. 144; cf. G. S. BAIN. R. PRICE. Profiles of (.../. p. 9; B. EBBINGHAUS, I. VISSER, A guide /.../. p. 24.

(18) Bovendien ondervond de SK heel wat problemen met de zogenaamde 'onafhankelijke vakbonden'. Vooral omwille van ideologische motieven weigerden deze tot de SK toe te treden. De SK nam in de praktijk een tolerante houding aan tegenover deze vakbonden. In 1907 wijzigde ze zelfs haar naam in Syndikale Kommissie van de BWP en de onathankelijke vakbonden.

(19) E. VANDERVELDE, Le cinquantenaire du PO.B. 1885-1935. Bruxelles: L'Eglantine, 1936, p. 210.

(20) SK, Verslag 1922 (1923), p. 98.

(21) Wanneer er in 1928 in de Centrale der Kleeding moeilijkheden ontstaan, maakt de Brusselse afdeling er zich van los en sleept in haar kielzog de hoedenmakers mee. In 1930 sluit de nieuw opgerichte Centrale Vereeniging der Hoedenmakers en Aanverwante Takken zich terug aan bij de SK.

(22) SK, Verslag 1919 (1920), p. 70.

(23) De Belgische vakbeweging. 19, 12 sept. 1925, pp. 261-262, cf. De Belgische vakbeweging, 22, 24 okt. 
1925. pp. 309-312; De Belgische vakbeweging. 15, 17 jul. 1926. pp. 219-220.

(24) C. STRIKWERDA. The Divided Class: Catholics vs. Socialists in Belgium, 1880-1914. In: Comparative Studies in Society \& History, 30(1988) p. 353.

(25) Inlichtings- en documentalieblad van de Algemeene Centrale van Bouw. Ameublement en Gemengde Vakken van Betgië, 117, 22 nov. 1937, p. 3.

(26) De Belgische vakbeneging, 11, 24 mei 1924, p. 150.

(27) De Belgische vakbeweging. II, 24 mei 1924, p. 151. Nochtans zat de syndicale leiding zelf verlegen om een coherente ideologische blauwdruk.

(28) Het ledenaantal voor 1938 heeft ongetwijfeld betrekking op het aantal 'ingeschreven leden', cf., Lannée sociale 1938-1939. Genève: BIT, 1939. p. 443. Omtrent de registratiebasis van het ledenciffer voor 1939 blijven we in het ongewisse. We vinden 570.000 leden op I januari 1940 terug in Lannée sociale 19391940, Genève: BIT, 1940, p. 366, cf. R. EBERTZHEIM, Les syndicats ouvricrs /.../. p. 8.

(29) De Belgische vakbeweging. 16. 2 aug. 1924, p. 233. cf. P. PASTURE, I. MAMPUYS, in de ban /.../. p. 90.

(30) G. VANTHEMSCHE, De werkloosheid /.../. p. 53. Voor een aanzet tot een uitgebreide verklaring. zie K. VANDAELE. Oorzaken van de /.../. pp. 86-197.

(31) AC, Verslag 1932-33 (1934), p. 98.

(32) De Belgische vakbeweging, 6, 20 juni 1935, p. 115.

\section{Bronnen}

Congresverslagen en -rapporten

- Centrale der Boekbewerkers (1925, 1938-40); Centrale der Steendrukkers (1920, 1924); Centrale der Boekbinders (1922-24); Belgische Boekdrukkersverbond (1923-39); Algemene Centrale (1922-38); Centrale der Steenbewerkers (1925, 1938): Algemeen Bediendensyndikaat (1937); Centrale Onderwijzend Personeel (1932); Textielcentrale (1924-39): Centrale der Kleeding (1932): Centrale der Lederbewerkers (1929-39); Centrale der Diamantbewerkers (1927); Centrale der Metaalbewerkers (1922-39); Centrale der Mijnwerkers (1937-39); Centrale der Openbare Diensten (1924, 1932); Nationaal Syndikaat S.P.T.T.Z.L. (1932); Syndikaat Burgerlijk Personeel Landsverdediging (1927, 1939): Centrale der Tabaksbewerkers (1928-1937); Centrale der Transportarbeiders (1924-38); Centrale der Voeding (1924-1948).

- SK, Verslagen (1921-37).

- BW, Verslag (1938).

\section{Periodieke publicaties}

- Le Travailleur du livre (1924-35); De Boekbewerker (1936-38): De Ontvoogding (1932-38): Inlichtings- en documentatieblad van de A/gemeene Centrale van Bouw, Ameublement en Gemengde Vakken van België (193438); Le Carrier (1920-39); De Bediende (1928-37); De Textielbewerker (1923-26); De Diamantbewerker (1919-40); De Metaalbewerker (1919-29); Louvrier Mineur (1935); De Beigische Tram (1926-38).

- De Belgische Vakbeweging (1920-39).

- Arbcidsblad. Brussel: ministerie van Arbeid, $1921-1939$.

- Lannée sociale. Genève: BIT. 1931. 40.

\section{Bibliografie}

- G. S. BAIN, R. PRICE, Profiles of Union Growth. A Comparative Statistical Portrait of Eight Countries, Oxford: Blackwell Publishers, 1980. $177 \mathrm{p}$.

- 1. BONDAS. Geschiedenis van de Centrale der Metaalarbeiders van België, 1887-1947. Zestig jaren van inspanning en strijd, Brussel: CMB, 1947, $198 \mathrm{p}$.

- L. CALMFORS. A. BOOTH, M. BURDA e.a., The Future of Collective Bargaining in Europe. In: T. BOERI, A. BRUGIAVINI, L. CALMFORS (eds.), The Role of Unions in the Twenty-First Century: A Study for the Fondazione Rodolfo Debenedetti, Oxford: Oxford University Press, 2001. pp. 1-I34. 
- J. BONDAS, Een halve eeuw syndicale actie. 1898-1948. Geschiedenis van de S.K., van het B.V.V. en van het A.B.V.V. Antwerpen: Excelsior, 1948, 477 p.

- I. BREPOELS. De Belgische Werkliedenpartij een halve eeuw oud. In: J. BREPOELS, M. SCHAEVERS, F. VANDENBROUCKE (red.), Eeuwige dilemma's. Honderd jaar socialistische partij, Leuven: Kritak, 1985, pp. II33.

- N. DETHIER, Centrale syndicale des travailleurs des mines de Belgique. 60 années d'action 1890-1950, La Louvière, s.n., 1950, 310 p.

- W. DEWACHTER. Politieke statistiek in België. Oproep bij het einde van 170 jaar België. In: Res Publica, 42(2000)2-3, pP. 379-390.

- B. DE WILDE. 'Vereenigd zijn we alles, onvereenigd zijn we niets'. 100 jaar socialistisch textielsyndicalisme 1898-1998, Gent: Ludion. 1998, 127 p.

- B. DE WILDE. Witte boorden, blauwe kielen. Patroons en arbeiders in de Belgische textielniviverheid in de $19 e$ en 20 e eeuw, Gent: Ludion, 1997, 403 p.

- B. EBBINGHAUS. I. VISSER, Trade Unions in Western Europe since 1945, Oxford: Mac Millan, 2000.

- R. EBERTZHEIM, Les syndicats ourriers en Belgique, Liège: BibliothèQue de l'École supérieure de sciences commerciales et économiques de l'Université de Liège, 34, 1959, $210 \mathrm{p}$.

- 1. FRANSEN. Van de straat naar de tafel: de evolutie naar paritair overleg (19|8-1940). In: Roodgloeiend. Bijdragen tot de geschiedenis van de Centrate der Metaalbewerkers van België, Gent: AMSAB, 1990, pp. 241293.

- P. HUDSON, History by Numbers. An Introduction to Quantitative Approaches, London: Arnold, 2000, 278 p.

- F. LEHOUCK, Het Belgische arbeiderssyndicalisme tijdens het begin van de regering-G. Theunis $(16$ december 1921-5 april 1925). In: Arbeidsblad. 88(1987)9-10. pp. 979-1009.

- C. MERTENS, Beknopte geschiedenis der Belgische boekbindersorganisatie, Brussel: Lucifer, 1923, 62 p.

- C. MERTENS, Le mouvement syndical en Belgioue. Amsterdam: Fédération Syndicale Internationale, 1925, 46 p.

- M. NAUWELAERTS, De socialistische syndikale beweging na de Eerste Wereldoorlog (1919-1921). In: Beigisch Tijdschrift voor de Nieuwste Geschiedenis, 4(1973)3-4. pp. 343-376.

- 1. NEUVILLE, Une génération syndicale. Bruxelles: La Pensée catholique, 1959. 168 p.

- P. PASTURE, I. MAMPUYS, In de ban van het getal. Ledenanalyse van het ACV 1900-1990, Leuven: HNA. 1990, $279 \mathrm{p}$.

- 1.-1. MESSIAEN, L. PEIREN, Een ceuw solidariteit 1898-1998, Brussel: ABW, 1998, 196 p.

- B. ROTHSTEIN, Labor-Market Institutions and Working-Class Strength. In: S. STEINMO, K. THELEN, F. LONGSTRETH (ed.), Structuring Politics. Historical Institutionalism in Comparative Analysis. Cambridge: Cambridge University Press. 1992, pp. 35-56.

- S. H. SCHOLL. 150 jaar katholieke arbeidersbeweging in Betgië (1789-1939). Tweede deel. De christendemocratie (1886-1914). Brussel: Arbeiderspers, 1965. 448 p.

- G. SPITAELS, Le mouvement syndical en Belgique, Bruxelles: Editions de l'Institut de sociologie, 1967, 96 p.

- C. STRIKWERDA, The Divided Class: Catholics vs. Socialists in Belgium, 1880-1914. In: Comparative Studies in Society \& History, 30(1988), pp. 333-359.

- C. STRIKWERDA, A House Divided. Catholics, Socialists, and Flemish Nationalists in Nineteenth-Century Befgium, Oxford: Rowman \& Littlefield Publishers, 1997, $454 \mathrm{p}$.

- K. VANDAELE, Oorzaken van de hoge syndicalisatiegraad in België, RUG, scriptie, 2000, 230 p.

- G. VANTHEMSCHE, De werkloosheid in België. 1929-1940, Berchem: EPO, 1989, 332 p.

- J. VISSER, I. WADDINGTON, Industrialization and Politics: a Century of Union Structural Development in Three European Countries. In: European lournal of Industrial Relations, 2(1996)1, pp. 2 1-53.

- B. WESTERN. Between Class and Market. Postwar Unionisation in the Capitalist Democracies, Princeton (New Jersey): Princeton University Press, 1997, 230 p. 